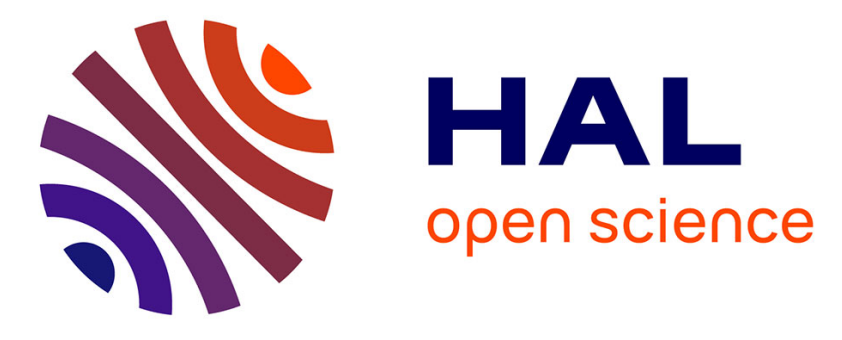

\title{
Arc-related high-K magmatism in the Ceuta Peninsula (Internal Rif, Spain): discovery and consequences
}

Emmanuelle Homonnay, Jean-Marc Lardeaux, Michel Corsini, Asmae El Bakili, Delphine Bosch, Olivier Bruguier, Mohamed Ouazzani Touhami

\section{- To cite this version:}

Emmanuelle Homonnay, Jean-Marc Lardeaux, Michel Corsini, Asmae El Bakili, Delphine Bosch, et al.. Arc-related high-K magmatism in the Ceuta Peninsula (Internal Rif, Spain): discovery and consequences. Geological Magazine, 2019, 10.1017/S0016756818000717 . hal-03018035

\section{HAL Id: hal-03018035 \\ https://hal.science/hal-03018035}

Submitted on 21 Nov 2020

HAL is a multi-disciplinary open access archive for the deposit and dissemination of scientific research documents, whether they are published or not. The documents may come from teaching and research institutions in France or abroad, or from public or private research centers.
L'archive ouverte pluridisciplinaire HAL, est destinée au dépôt et à la diffusion de documents scientifiques de niveau recherche, publiés ou non, émanant des établissements d'enseignement et de recherche français ou étrangers, des laboratoires publics ou privés. 


\title{
Arc-related high-K magmatism in the Ceuta Peninsula (Internal Rif, Spain): discovery and consequences
}

\author{
Emmanuelle Homonnay ${ }^{1}$, Jean-Marc Lardeaux ${ }^{1,2}$, Michel Corsini ${ }^{1}$, Asmae \\ El Bakili ${ }^{1,3}$, Delphine Bosch ${ }^{4}$, Olivier Bruguier ${ }^{4}$ and Mohamed Ouazzani-Touhami ${ }^{5}$
}

${ }^{1}$ Géoazur, Université Côte d'Azur, CNRS, IRD, Observatoire de la Côte d'Azur, UMR 7329, 250, rue Albert-Einstein, 06560 Sophia Antipolis, France, ${ }^{2}$ Czech Geological Survey, Centre for Lithospheric Research, Klárov 3, 11821 Prague 1, Czech Republic, ${ }^{3}$ Faculté des Sciences de Rabat, Université de Mohammed V, 4 avenue Ibn Batouta, Rabat, Morocco, ${ }^{4}$ Géosciences Montpellier, UMR UM-CNRS 5243, Université Montpellier, CC 060, place Eugène Bataillon, 34095 Montpellier cedex 5, France and ${ }^{5}$ Département de Géologie, Université Abdelmalek Esaadi, 93003 Tetouan, Morocco

\begin{abstract}
We document the occurrence of micro-diorite magmatic sills, with magmatic enclaves, in the Ceuta Peninsula within metapelites from the Lower Sebtides units (Internal Rif). All magmatic rocks show a primary magmatic mineralogy and geochemical signature diagnostic for high-K calc-alkaline to shoshonitic island arc magmatism. Moreover, these rocks are significantly affected by secondary metamorphic transformations under greenschist- to amphibolite-facies conditions, regionally dated at c. $21 \mathrm{Ma}$. Geometric relationships between the sills and the main regional foliation, developed under intermediate-pressure granulite-facies conditions at c. 28 $\mathrm{Ma}$, demonstrate that the sills emplaced during the late stage of this main tectonic event. New $\mathrm{U}-\mathrm{Pb}$ in situ analyses of monazite performed on the micro-diorite sills provide an age of $20.64 \pm 0.19 \mathrm{Ma}$, coherent with this chronological framework and interpreted as the age of greenschist-facies re-equilibration. The discovery of pre-Miocene high- $\mathrm{K}$ calc-alkaline to shoshonitic arc-related magmatism is clearly consistent with the subduction context proposed for the Alboran Basin evolution, according to geophysical investigations. In this framework, the Lower Sebtides units could be considered as part of the upper plate of the subduction system, while the Upper Sebtides must be regarded as the lower subducted plate.
\end{abstract}

\section{Introduction}

Located in the western tip of the Mediterranean, the Gibraltar arc consists of the Alboran Basin surrounded by the Betic (in Spain) and the Rif (in Morocco) orogenic belts built, since late Mesozoic time, in the context of Africa and Eurasia plate convergence (Fig. 1). Today, the geodynamic evolution of the internal zone of these cordilleras (i.e. the Alboran domain) is considered to be the result of subduction followed by slab rollback, which produced the opening of a back-arc basin (e.g. Royden, 1993; Lonergan \& White, 1997; Faccenna et al. 2004, 2014; Spakman \& Wortel, 2004; Vergés \& Fernàndez, 2012; Bezada et al. 2013; Van Hinsbergen et al. 2014). Such a scenario with a retreating slab, migrating behind the orogenic wedge is also assumed in other domains of the Mediterranean such as the Calabrian arc (e.g. Faccenna et al. 2001, 2002) or the Aegean arc (e.g. Jolivet \& Brun, 2010; Jolivet et al. 2013).

Numerous geological, petrological, geochemical and geochronological studies were carried out on the internal zones of the Betic and the Rif belts in order to constrain the geodynamic evolution of the Alboran domain (e.g. Beccaluva et al. 2007; Duggen et al. 2008; Conticelli et al. 2009; Lustrino et al. 2011; Carminati et al. 2012). However, in spite of these detailed studies, no expression of arc-related calc-alkaline magmatism has ever been documented so far in the Internal Rif. In this paper we unravel for the first time the occurrence of subduction-related magmatism in the Ceuta Peninsula, located in the internal zone of the Rif belt.

\section{Geological context}

The Rif Cordillera, located in the northern part of Morocco, consists of stacked sedimentary and metamorphic units thrust onto foreland basins. Classically, three main structural domains are recognized in this orogenic system (Fig. 1b): (i) the External zone, (ii) the Flysch zone and (iii) the Internal zone (or Alboran domain, see Michard et al. 1991; Chalouan et al. 2008). The Internal Rif consists of three units, namely, from top to bottom, the Dorsale calcaire, the Ghomarides unit and the Sebtides unit (Fig. 1b, e.g. Chalouan et al. 2001). The Sebtides unit is composed of a stack of high- to low-grade metamorphic rocks, subdivided into the prePermian Lower Sebtides and the Palaeozoic to Triassic Upper Sebtides (Chalouan et al. 2008). In the Ceuta area, two sub-units are distinguished in the Lower Sebtides: the Ceuta 


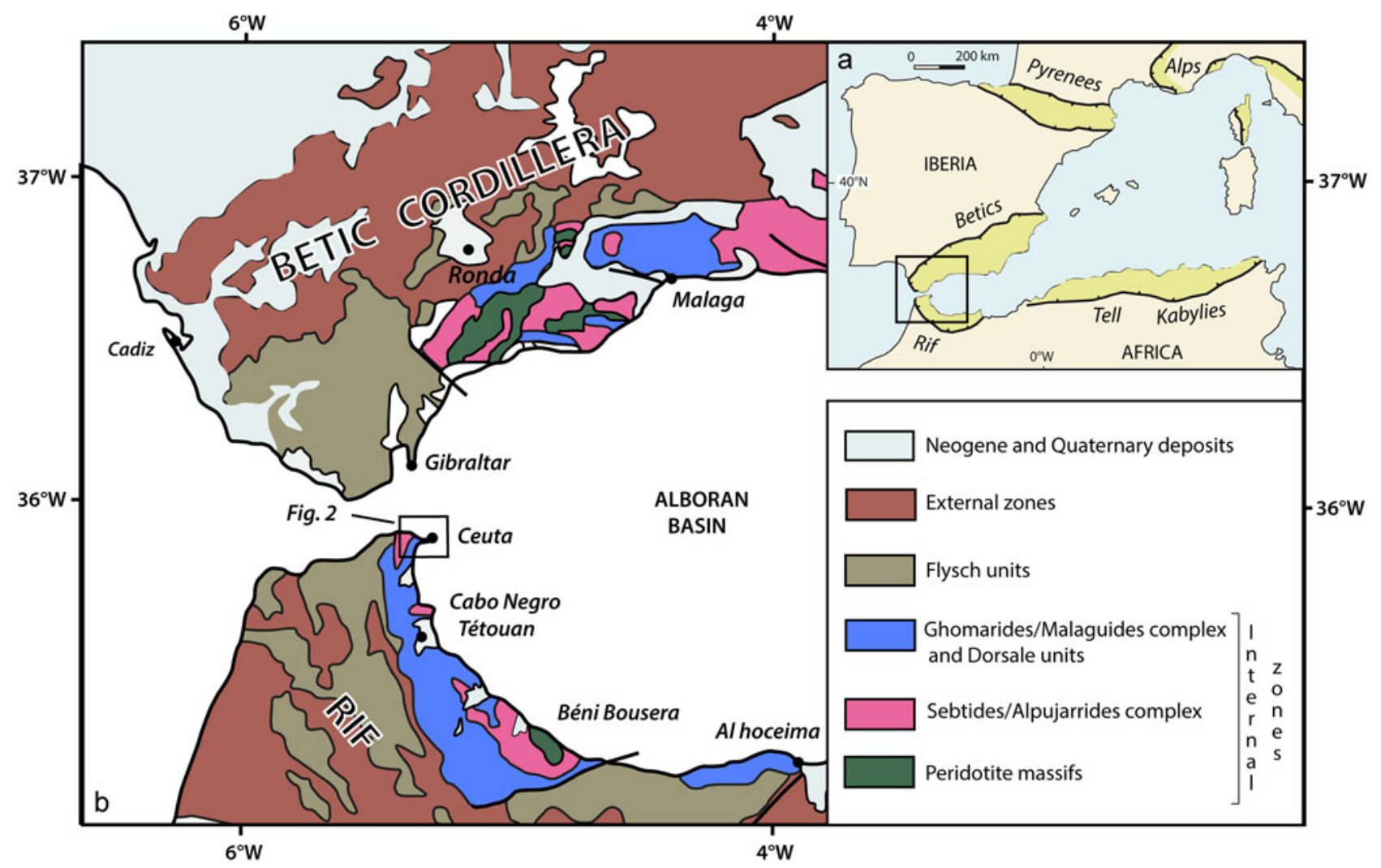

Fig. 1. (Colour online) (a) Location of the Gibraltar arc and Alboran Basin in the framework of the Western Mediterranean and peri-Mediterranean orogenic belts (light green). (b) Structural map of the Gibraltar arc.

Upper Unit (CUU) and the Monte Hacho Lower Unit (MHLU). The CUU is composed of migmatitic metapelites containing peridotite lenses and boudins of high- to ultra-high-pressure granulites at its base (Kornprobst, 1974; Ruiz-Cruz \& De Galdeano, 2012, 2013), overthrust upon the migmatitic orthogneisses of the MHLU (Fig. 2, Kornprobst, 1974; Homonnay et al. 2018). Thrust tectonics developed under intermediate-pressure granulite-facies metamorphism before Miocene time, probably during Oligocene time (Homonnay et al. 2018). In this domain, three ductile deformation stages (D1-D3) have been identified, where S1-S3 foliations are associated with distinctive metamorphic assemblages (Homonnay et al. 2018). In both Lower Sebtides units, an S2 composite foliation, bearing a well-developed stretching lineation L2, is the dominant regional fabric whatever the lithology. In the uppermost unit, pre-D2 fabrics (i.e. D1/S1) are locally preserved in volumes (i.e. lozenge-shaped blocks) that escaped overprinting by the pervasive S2. In both units, D3 structures consist of localized normal ductile shear zones associated with an S3 foliation. Detailed microstructural, mineralogical and geochronological investigations (Homonnay et al. 2018) demonstrate that:

(1) D1 was contemporaneous with high-pressure/high-temperature metamorphic conditions (high-pressure granulite facies) of unknown age;

(2) D2 developed, contemporaneously with thrust tectonics, under intermediate-pressure granulite-facies conditions (7-10 kbar and $780-820^{\circ} \mathrm{C}$ ) before $28 \mathrm{Ma}$;

(3) D3 is characterized by metamorphic re-equilibration at the boundary between amphibolite- and greenschist-facies conditions (400-550 ${ }^{\circ} \mathrm{C}$ and $1-3$ kbar) during early Miocene time (i.e. c. $21 \mathrm{Ma}$ ).

In the most western part of the Ceuta area, the Upper Sebtides (Federico units) underwent an Alpine, probably Oligocene, highpressure/low-temperature metamorphism typical of subduction zone conditions (Bouybaouene et al. 1995; Goffe et al. 1996; Michard et al. 1997; Janots et al. 2006).

\section{Evidence for high-K calc-alkaline magmatism in the Lower Sebtides}

\section{3.a. Field observations}

Metapelites from the CUU present a main NE-striking (N30 to N50) S2 foliation plane, gently to moderately dipping (20 to $50^{\circ}$ ) towards the NW (Fig. 2). This foliation is marked by the alternation of quartz-feldspars and garnet-biotite-sillimanite-rich levels as well as by the alternation of centimetric quartzo-feldspathic leucosomes and biotite-sillimanite mesosomes (Fig. 3a). This main D2 deformation episode, synchronous with partial melting of the metapelites, is also contemporaneous with the thrusting of the CUU over the MHLU (Homonnay et al. 2018).

In these metapelites we found several pluricentimetric to plurimetric magmatic sills parallel to the main S2 foliation plane (Fig. 3a, $\mathrm{b}, \mathrm{c})$. In these 'micro-granitoid' sills we recognized two types of enclaves: (1) enclaves of migmatitic metapelites (i.e. host rock, Fig. 4a) and (2) granular to microgranular magmatic enclaves (Fig. 4b). The cores of the magmatic sills are clearly not deformed and contain a well-preserved microgranular porphyric texture 


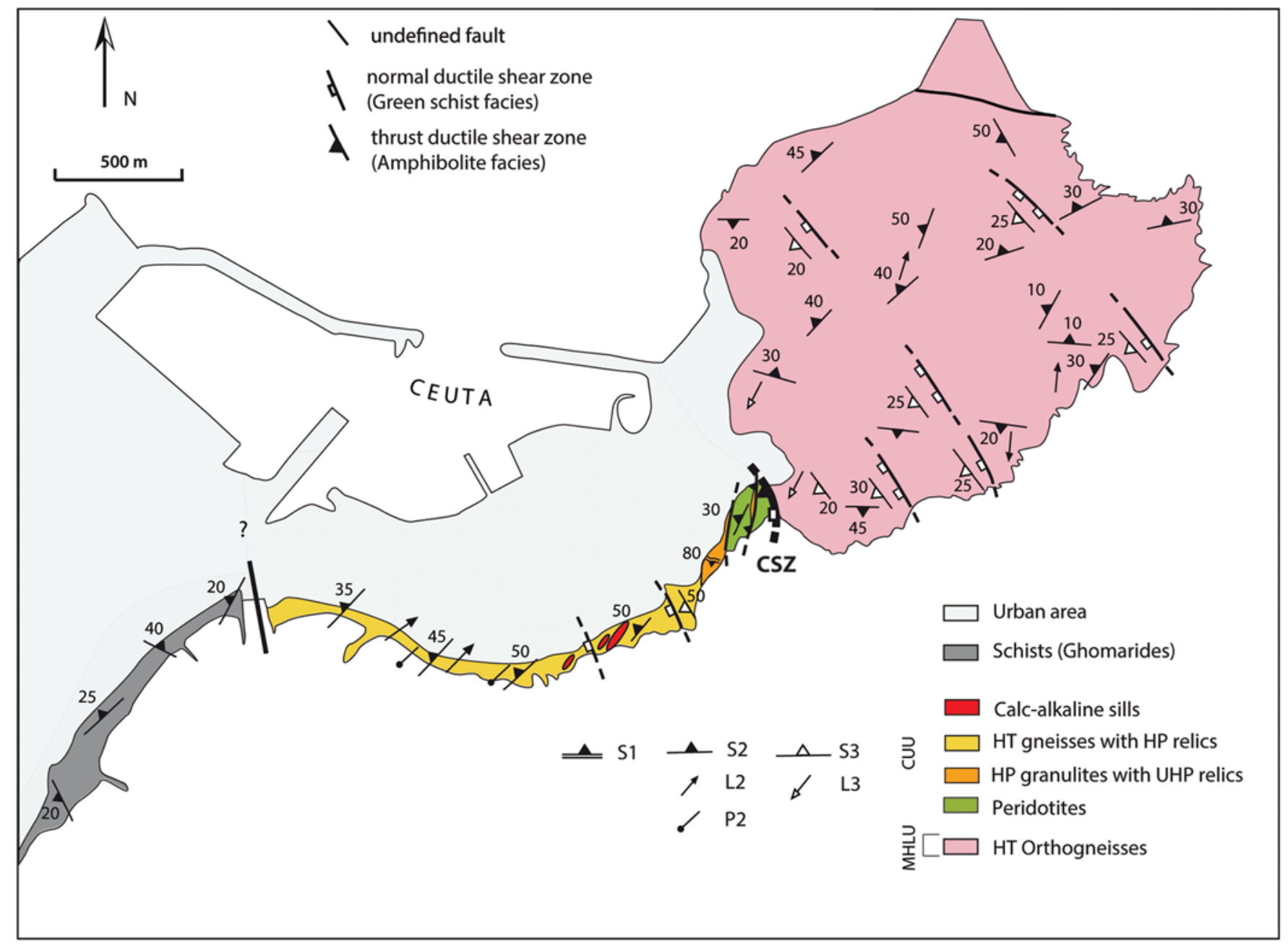

Fig. 2. (Colour online) Geological map showing the location of the magmatic sill within the structural framework of the Ceuta Peninsula (modified after Homonnay et al. 2018). CUU - Ceuta Upper Unit; MHLU - Monte Hacho Lower Unit; CSZ - Ceuta Shear Zone. See Figure 1b for location.

(Fig. 3d). On the other hand, the edges of the sills display preferred mineral orientation interpreted as a magmatic flow-fabric (Fig. 3b,c,e). This interpretation is supported by enclave alignments parallel to the main foliation of the surrounding rocks (Fig. 3b). These structural observations are typical for syn- to late-tectonic (i.e. D2 deformation event) magma emplacement. In such a case, the magmatic sills were emplaced in thermal equilibrium with the surrounding metapelites.

\section{3.b. Petrographic observations}

The magmatic sills present a microgranular porphyric texture, while magmatic fluidality is visible in thin-sections from the edges of the sills (Fig. 5a). The sills contain a primary magmatic assemblage essentially composed of feldspars, quartz, biotites and oxides (ilmenite and magnetite). Feldspars occur as subhedral to anhedral large-sized grains (1-5 mm) (Fig. 5b) and present a magmatic zonation. They are predominantly plagioclases $\left(\mathrm{An}_{7}-\mathrm{An}_{25}\right)$, which exhibit polysynthetic twinning. K-feldspars (orthoclase, microcline) are observed in minor amounts and orthoclase shows Carlsbad twinning. In the groundmass, xenomorphic quartz grains show wavy extinctions. Biotite appears as small $(<1 \mathrm{~mm})$ brown, strongly pleochroic grains in the groundmass or as minute inclusions in large plagioclase grains (Fig. 5b). In the largest biotite grains, needle-shaped rutile developed along cleavage planes. In addition, we frequently observed a 'ghost' mineral with a rectangular or rhomboidal shape (around $5 \mathrm{~mm}$ ), which is totally replaced by an association of chlorite, muscovite and epidote (Fig. 5c). Although the nature of this mineral cannot be definitely determined, the secondary mineral association together with the mineral shapes strongly suggests a primary magmatic amphibole or a primary magmatic pyroxene. Indeed, in one thin-section we recognized one fragment of a rectangular-shaped pyroxene within the pseudomorphic aggregate. Magnetite occurs as more or less rhombohedral isotropic crystals in the groundmass, while ilmenite is found as elongated dark brown frequently altered grains. Accessory minerals are titanite, apatite, monazite and zircon.

This primary magmatic mineral association of plagioclase + quartz + K-feldspar + biotite $+\mathrm{Fe}-\mathrm{Ti}$ oxide $+\mathrm{Fe}-\mathrm{Mg}$-mineral (amphibole and/or pyroxene) indicates a moderately differentiated magmatic rock (micro-granodiorite or micro-diorite). The lack of primary magmatic muscovite or aluminium silicates together with the presence of amphibole or pyroxene, Fe-Ti oxides and titanite in the magmatic association is typical for calc-alkaline magmas, i.e. Hybrid Late Orogenic $\left(\mathrm{H}_{\mathrm{LO}}\right)$ or Hybrid Continental Arc $\left(\mathrm{H}_{\mathrm{CA}}\right)$ 

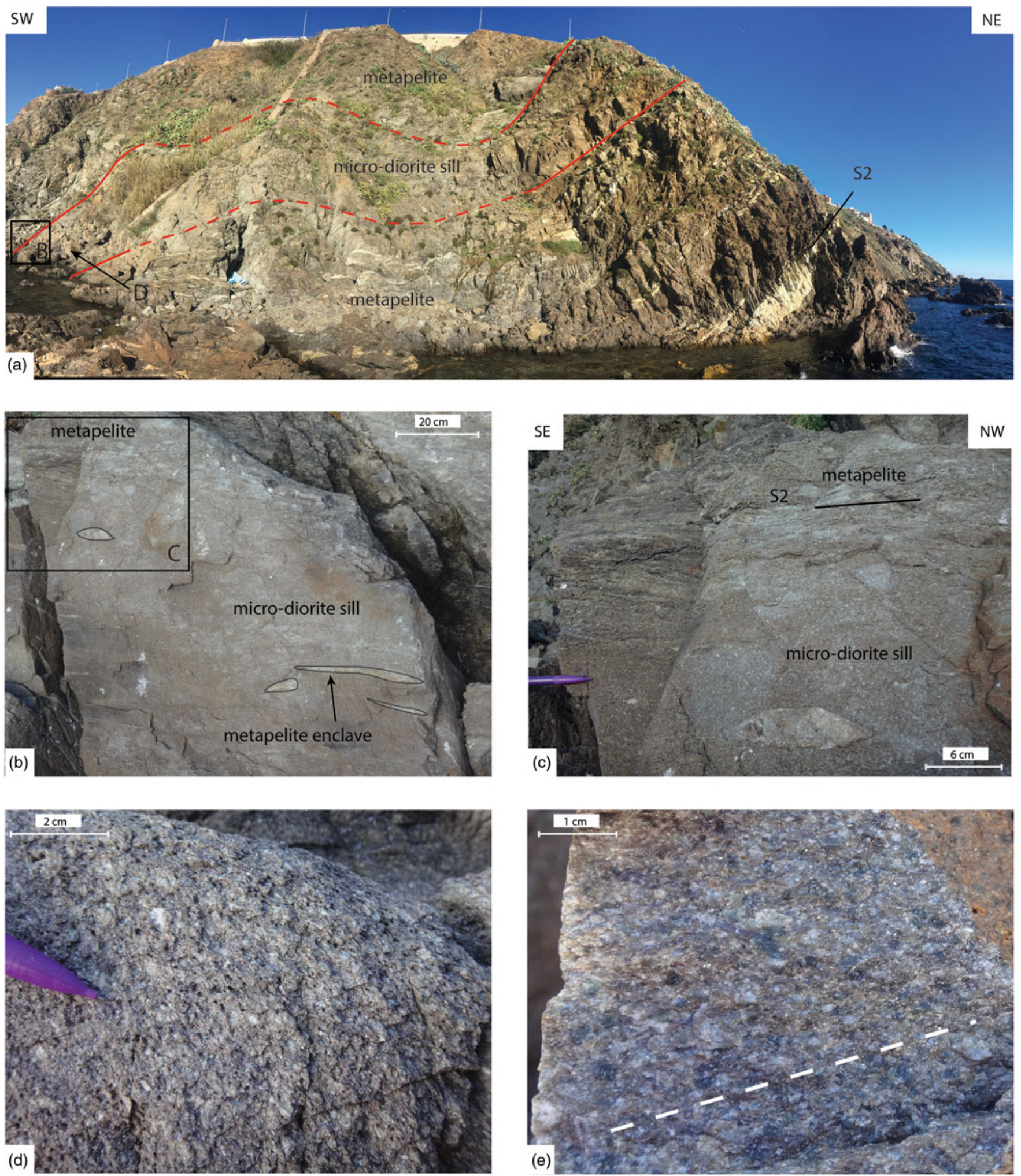

Fig. 3. (Colour online) Field observations. (a) Decametric sill parallel to the main $\mathrm{S} 2$ metapelite foliation plane. (b) Edge of the sill with magmatic fluidality and enclave alignments parallel to the main S2 foliation plane. (c) Contact between the micro-diorite sill and the metapelite. (d) Microgranular porphyric texture preserved in the core of the sill. (e) Magmatic mineral orientation (underlined by white dashed lines) within the micro-diorite sill.

magmatic series in the mineralogical/petrogenetic classification of Barbarin (1990) and thus of mixed (crustal + mantle) origin.

Most magmatic minerals underwent secondary metamorphic transformations (Fig. 5c). Feldspars are partly or totally replaced by patches of albite and white mica. White micas also occur as radial aggregates along magmatic grain boundaries. Chlorite forms pseudomorphic patches within magmatic phases. In some samples, epidote developed at the expense of primary $\mathrm{Fe}-\mathrm{Mg}$ magmatic minerals. 

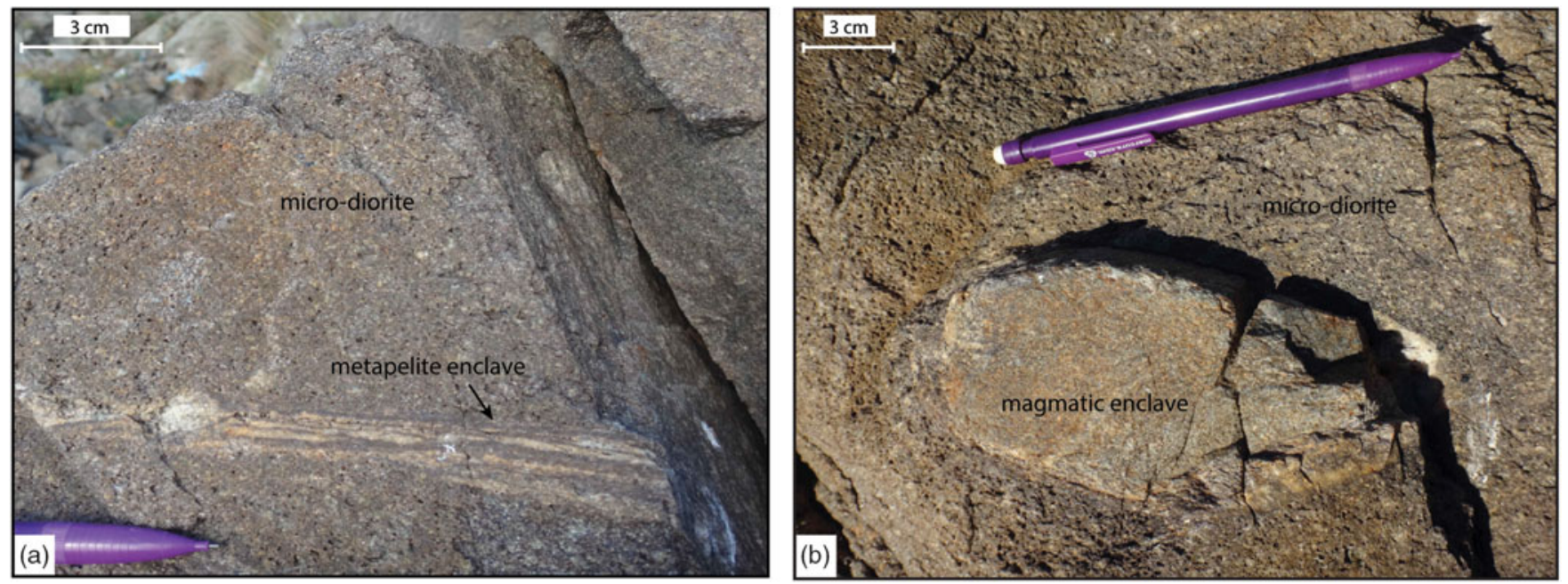

Fig. 4. (Colour online) Enclaves observed within the micro-diorite sill. (a) Metapelite enclave. (b) Magmatic enclave with microgranular texture.

The magmatic enclaves display a magmatic mineral association of plagioclase, amphibole, pyroxene and minor quartz (Fig. 6). Plagioclase occurs as lath-shaped crystals that show polysynthetic twinning. Amphibole is anhedral, green coloured and pleochroic with, when observable, an extinction angle of about $20^{\circ}$. Millimetre-sized pyroxene grains occur as anhedral crystals and are largely replaced by secondary metamorphic minerals. Quartz grains, with irregular grain boundaries, are scattered in the matrix. Accessory magmatic minerals include magnetite and/or ilmenite, titanite and zircon. Secondary metamorphic minerals are well developed; plagioclases are frequently converted to fine-grained white mica, while amphibole and pyroxene are partly or completely pseudomorphosed by muscovite, chlorite and epidote.

The development of a secondary metamorphic mineral association (i.e. white mica + chlorite + quartz + albite \pm epidote assemblage) in the magmatic sills and their enclaves attests to a severe metamorphic re-equilibration at the boundary between amphibolite- and greenschist-facies conditions (i.e. synchronous with the D3 tectonic event; see Homonnay et al. 2018 for discussion). Thus, both the magmatic sills and surrounding metapelites are affected by D3 metamorphism, and consequently, field observations together with petrographic analysis are compatible with syn- to late-D2 and pre-D3 magmatic sill emplacement.

\section{3.c. Geochemical investigations}

Because the magmatic sills are significantly affected by D3 metamorphism, in order to investigate the geochemical characteristics of these magmatic rocks we sampled the magmatic rocks only in the largest and best-preserved sill. In this sill, in view of outcrop quality, we found only two samples of micro-granitoids with well-preserved magmatic texture (SEB12-04 and CEU14-05) and one enclave (CEU17-23E), also very well preserved. These three samples were selected for major- and trace-element chemical analyses. Bulk rock compositions were obtained by inductively coupled plasma atomic emission spectrometry (ICPAES) and inductively coupled plasma mass spectrometry (ICPMS), for major and trace elements, respectively, on rock powders at the Geochemical and Petrographical Research Centre in Nancy (SARM laboratory, CNRS-CRPG; Table 1) following the procedure described in Carignan et al. (2001).
In the total alkalis versus silica classification (i.e. TAS diagram after Le Maitre et al. 1989), the 'micro-granitoid' samples are micro-diorites, while the microgranular enclave is a less differentiated micro-gabbrodiorite (Fig. 7a). Moreover, with respect to $\mathrm{SiO}_{2}$ and $\mathrm{K}_{2} \mathrm{O}$ (i.e. in the classification of Peccerillo \& Taylor, 1976), all these magmatic rocks have a geochemical signature typical for high-K calc-alkaline magmas (Fig. 7b).

However, the identification of the geochemical characteristics of magmatic rocks re-equilibrated during regional metamorphism is still delicate because of the mobility of the chemical elements during fluid-assisted metamorphism (Bridgwater, 1989; Ferry, 1994). Numerous studies have already shown that major elements as well as some trace elements, mainly large ion lithophile elements (LILE) (e.g. Rb, Cs, Sr, Ba) and light rare earth elements (LREE) (e.g. La, Ce, $\mathrm{Nd}$ ), are considered to be the most mobile elements under greenschist- and amphibolite-facies conditions, whatever the considered lithology (Bridgwater, 1989; Potdevin et al. 1989; Lawrie, 1992; Ague, 1994, 2003; Roser \& Nathan, 1997; Brewer \& Menuge, 1998; Masters \& Ague, 2005; Zheng et al. 2009). Therefore, in order to improve the characterization of the geochemical signature of the studied samples, we selected diagrams suitable for magmatic rocks, using only minor and trace elements considered immobile during metamorphic processes.

First, in the Winchester \& Floyd (1977) magmatic rock classification including its modification by Pearce (1996), based on immobile element ratios such as $\mathrm{Zr} / \mathrm{Ti}$ versus $\mathrm{Nb} / \mathrm{Y}$, the studied samples range in the field of gabbroic and dioritic rock types (Fig. 8a). Second, we used the accurate Th-Co diagram proposed by Hastie et al. (2007) for magmatic rocks transformed under greenschist-facies conditions (Fig. $8 \mathrm{~b}$ ) and the $\mathrm{Th} / \mathrm{Yb}$ versus $\mathrm{Ta} /$ Yb diagram (Fig. 8c) from Pearce (1983). In these diagrams, the three samples are micro-gabbrodiorites and diorites, whereas their compositions still have a geochemical signature typical for the high-K to shoshonitic series.

Trace-element discriminant diagrams are often considered an important way to determine the tectonic environment of magma formation (Pearce, 1983; Pearce et al. 1984). However, traceelement compositions are also a function of source components and the crystallization history of the melts (Rollinson, 1993; Frost et al. 2001). Since trace-element diagrams can discriminate various tectonic settings, the composition of the studied samples was 

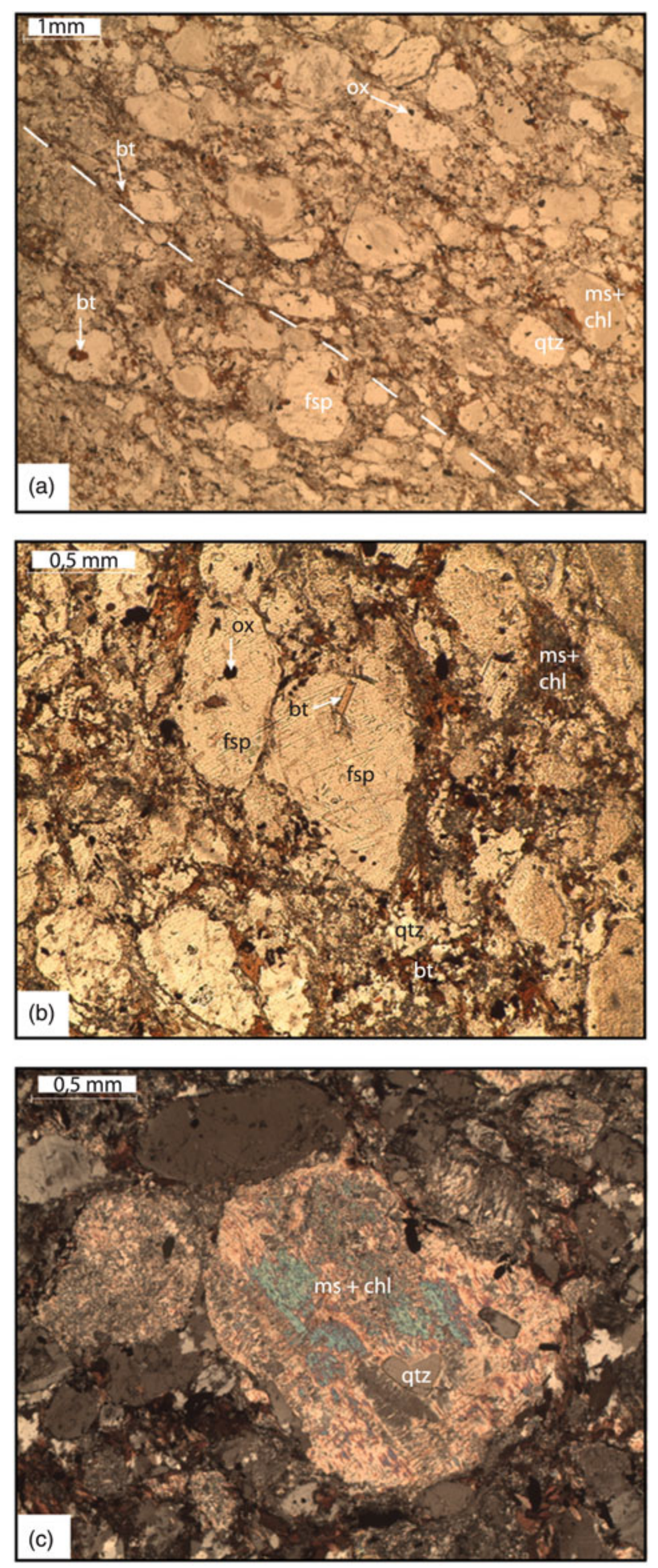

Fig. 5. (Colour online) Thin-section photomicrographs of the micro-diorite sills. (a) Magmatic mineral fluidality marked by white dashed lines (plane-polarized light). (b) Microgranular porphyric texture (plane-polarized light). (c) Typical 'ghost' mineral totally replaced by muscovite and chlorite \pm quartz (cross-polarized) fsp - feldspar; bt - biotite; ox - oxide; qtz - quartz; ms - muscovite; chl - chlorite.

plotted on some of these diagrams (Fig. 9). In the discriminant diagrams proposed by Pearce \& Cann (1973) and Pearce (1982) (Ti/ $\mathrm{Zr} / \mathrm{Y}$ in Fig. 9a and $\mathrm{Cr}$ versus $\mathrm{Y}$ in Fig. 9b, respectively), the three samples plot in the calc-alkaline and volcanic arc fields. In the Th/ Hf versus Ta/Hf diagram (Schandl \& Gorton, 2002), samples plot

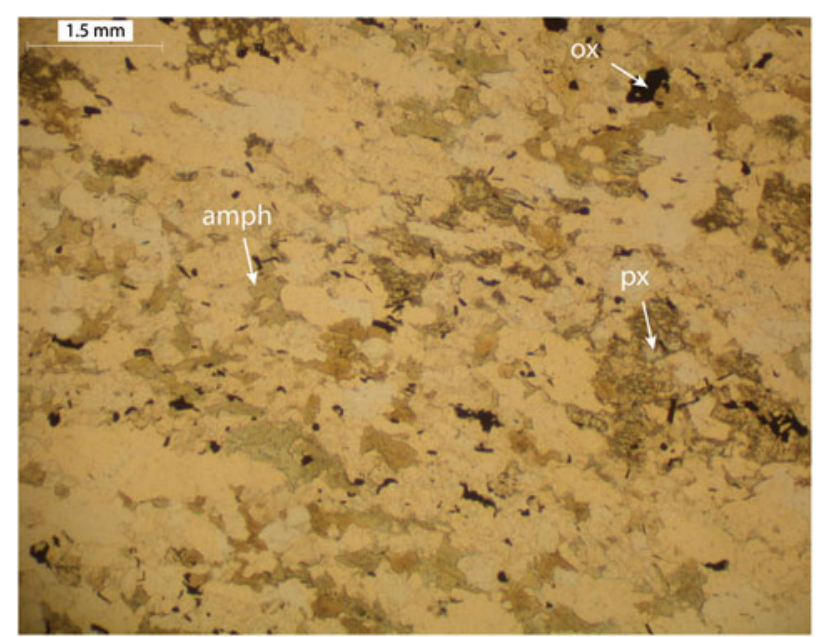

Fig. 6. (Colour online) Thin-section photomicrograph of a magmatic enclave (planepolarized light). The micro-porphyric texture is underlined by crystals of amphibole (amph), pyroxene (px) and oxides (ox). The domains in white correspond to plagioclase and minor quartz.

in the active continental margin field (Fig. 9c). Moreover, the two micro-diorites typically have an intermediate rock composition. Consequently, we felt it was also interesting to confront their chemical signatures with discriminant diagrams established for granitoids. In the $\mathrm{Nb}$ versus $\mathrm{Y}$ diagram from (Pearce et al. 1984), the two samples plot in the volcanic arc and syn-collisional granitoid field (Fig. 9d), while using the more accurate Ta versus Yb diagram proposed by Pearce et al. (1984) to distinguish between volcanic arc and syn-collisional granitoids, our samples plot in the volcanic arc granitoid field (Fig. 9e).

Altogether, the geochemical characters of the studied sills are consistent with a high-K calc-alkaline magma formed within a continental magmatic arc.

\section{U-Pb dating}

\section{4.a. Analytical method}

$\mathrm{U}-\mathrm{Th}-\mathrm{Pb}$ dating was performed on monazites and one xenotime from the micro-diorite SEB12-04. In situ analyses were achieved on thin-sections, in order to keep the microstructural context of the analysed minerals. Prior to LA-ICP-MS in situ U-Th-Pb analyses, minerals were examined with backscattered electrons (BSE) (Fig. 10), using a scanning electron microscope (SEM) at the CRHEA in Sophia Antipolis (Valbonne, France), to reveal the internal structure of the minerals. The operating conditions were $15 \mathrm{kV}$ accelerating voltage and a $17 \mathrm{nA}$ beam current. In situ $\mathrm{U}-\mathrm{Th}-\mathrm{Pb}$ analyses were performed at Geosciences Montpellier (University of Montpellier, France) by laser ablation (LA)-ICPMS using a Lambda Physik CompEx 102 Excimer laser coupled to an Element XR sector field ICP-MS at the AETE-ISO regional facility (OSU OREME). Laser spot sizes were $15 \mu \mathrm{m}$. Before analysis, the laser was first fired to clean the sample surface (ten pulses). The targeted mineral was subsequently ablated under ultrapure helium in a $15 \mathrm{~cm}^{3}$ circular-shaped ablation cell with an energy density of $12 \mathrm{~J} / \mathrm{cm}^{2}$ at a frequency of $2 \mathrm{~Hz}$ during $45 \mathrm{~s}$. A gas blank was measured during $15 \mathrm{~s}$ before each analysis. Analyses of unknown monazite grains were bracketed by analyses of the Manangotry monazite standard (Poitrasson et al. 2000). Repeated analyses of this reference mineral were used to correct 
Table 1. Chemical analyses: major elements (wt \%), minor and trace elements (ppm)

\begin{tabular}{|c|c|c|c|}
\hline Sample & SEB12-04 & CEU14-05 & CEU17-23E \\
\hline & micro-diorite & micro-diorite & enclave \\
\hline $\mathrm{SiO}_{2}$ & 59.2 & 61.1 & 54.0 \\
\hline $\mathrm{Al}_{2} \mathrm{O}_{3}$ & 19.2 & 17.9 & 15.9 \\
\hline $\mathrm{Fe}_{2} \mathrm{O}_{3}(\mathrm{t})$ & 8.1 & 7.0 & 8.0 \\
\hline $\mathrm{MnO}$ & 0.1 & 0.1 & 0.1 \\
\hline $\mathrm{MgO}$ & 2.5 & 2.3 & 5.9 \\
\hline $\mathrm{CaO}$ & 1.3 & 1.7 & 7.3 \\
\hline $\mathrm{Na}_{2} \mathrm{O}$ & 1.3 & 1.0 & 3.1 \\
\hline $\mathrm{K}_{2} \mathrm{O}$ & 3.3 & 3.6 & 2.1 \\
\hline $\mathrm{TiO}_{2}$ & 1.0 & 0.9 & 0.6 \\
\hline $\mathrm{P}_{2} \mathrm{O}_{5}$ & 0.0 & 0.2 & 0.7 \\
\hline LOI & 4.2 & 4.6 & 1.6 \\
\hline TOTAL & 100.1 & 100.3 & 99.4 \\
\hline $\mathrm{Ba}$ & 502.6 & 403.3 & 835.8 \\
\hline Co & 20.1 & 15.6 & 26.3 \\
\hline $\mathrm{Cr}$ & 113.0 & 97.0 & 198.6 \\
\hline $\mathrm{Er}$ & 3.2 & 2.8 & - \\
\hline $\mathrm{Eu}$ & 1.6 & 1.4 & - \\
\hline $\mathrm{Ga}$ & 26.5 & 23.9 & 22.1 \\
\hline $\mathrm{Hf}$ & 5.8 & 4.7 & 3.0 \\
\hline La & 47.8 & 41.9 & - \\
\hline $\mathrm{Lu}$ & 0.5 & 0.4 & - \\
\hline $\mathrm{Nb}$ & 15.5 & 14.0 & 9.2 \\
\hline $\mathrm{Nd}$ & 42.2 & 35.2 & - \\
\hline $\mathrm{Pb}$ & 21.9 & 17.1 & 13.0 \\
\hline $\mathrm{Pr}$ & 11.1 & 9.3 & - \\
\hline $\mathrm{Rb}$ & 131.1 & 147.1 & 55.9 \\
\hline Sc & 20.8 & 18.1 & 21.7 \\
\hline $\mathrm{Sm}$ & 8.2 & 6.9 & - \\
\hline $\mathrm{Sr}$ & 117.0 & 77.9 & 478.9 \\
\hline $\mathrm{Ta}$ & 1.3 & 1.4 & 0.6 \\
\hline $\mathrm{Tb}$ & 1.0 & 0.9 & - \\
\hline Th & 15.9 & 13.3 & 8.9 \\
\hline U & 3.1 & 3.2 & - \\
\hline V & 158.7 & 137.3 & 212.8 \\
\hline Y & 32.0 & 27.5 & 18.8 \\
\hline $\mathrm{Yb}$ & 3.0 & 2.9 & 3.0 \\
\hline $\mathrm{Zr}$ & 219.0 & 169.8 & 98.8 \\
\hline
\end{tabular}

for inter-element fractionation and for mass bias factor corrections (see details in Bosch et al. 2011). Quoted ratios (see Table 2) correspond to measured ratios corrected for background and mass discrimination (+ elemental fractionation for the ${ }^{206} \mathrm{~Pb} /{ }^{238} \mathrm{U}$ ratios). All ages have been calculated using the $\mathrm{U}$ and $\mathrm{Th}$ decay constants recommended by Steiger \& Jäger (1977). Analytical data were plotted and ages were calculated using the IsoplotEx program
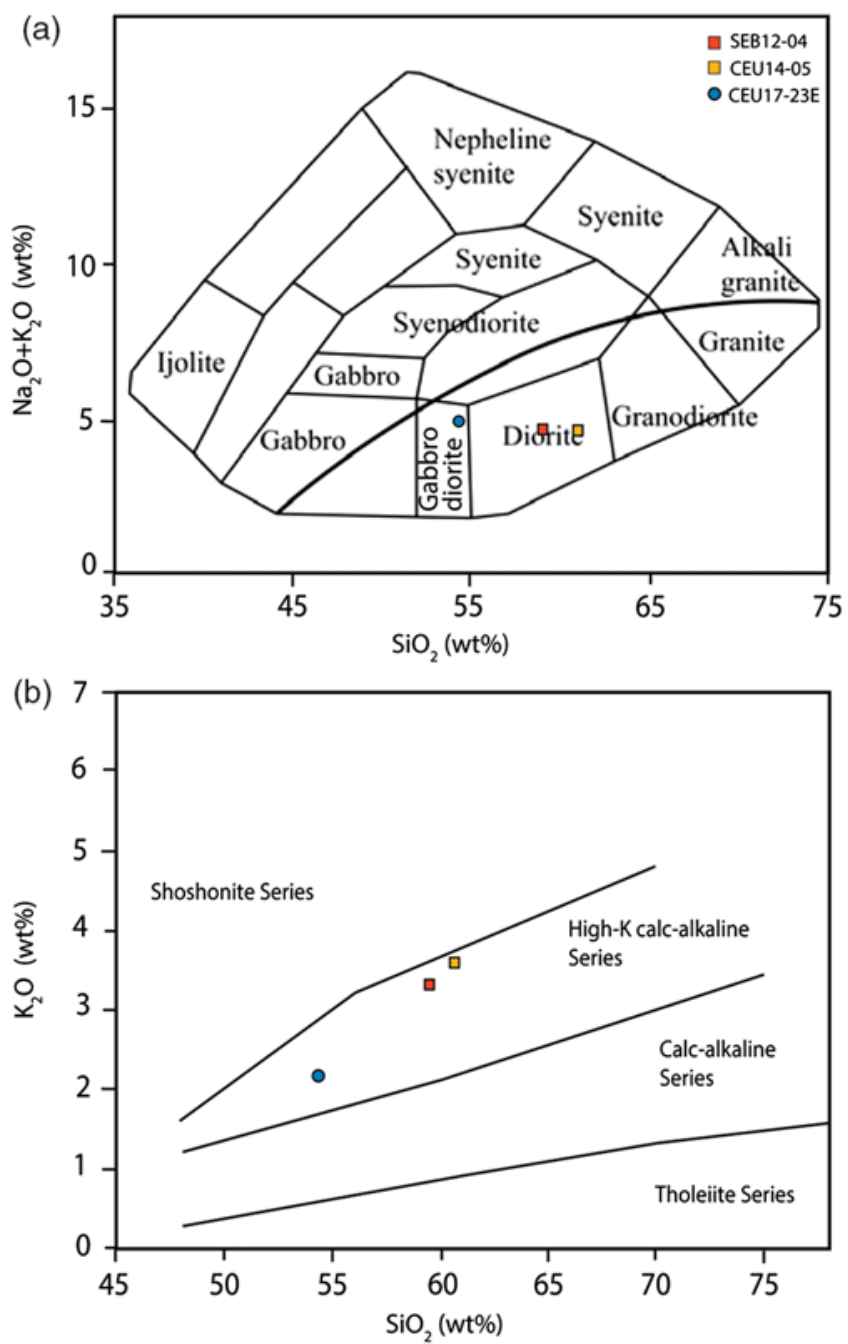

Fig. 7. (Colour online) Rock classification diagrams using major elements. (a) TAS diagram for igneous rocks after Cox et al. (1979). (b) Rock series discriminant diagram from Peccerillo \& Taylor (1976).

(Ludwig, 2003). Individual analyses in Table 2 and in Concordia plots (Fig. 11) are $\pm 1 \sigma$ errors, and uncertainties in ages are quoted in the text at the $2 \sigma$ level.

\section{4.b. Results}

Eighteen monazites and one xenotime were analysed from the sample SEB12-04. Under BSE imaging, 11 monazites display a homogeneous structure (Fig. 10a), whereas seven show either a light grey core surrounded by a dark grey rim (Fig. 10b; mnz3, mnz12, mnz13) or irregular light grey patches (Fig. 10c; mnz 2, mnz9, mnz16, mnz18) suggesting recrystallization of preexisting minerals (e.g. Bosch et al. 2002). The monazites sometimes contain inclusions (mnz1, 3-6, 15-18; Fig. 10c) and have a rounded or elongated shape. The shape of the monazite, and lack of oscillatory zoning, is not consistent with crystallization from a melt, as observed for magmatic monazite (e.g. Bruguier et al. 2009). The xenotime is homogeneous, rounded in shape with undulant rims. Thirty-nine analyses were performed on 18 monazite grains (see Table 2) and two analyses were performed on the xenotime grain identified in the thin-section. Despite the observed differences in internal structures, most 

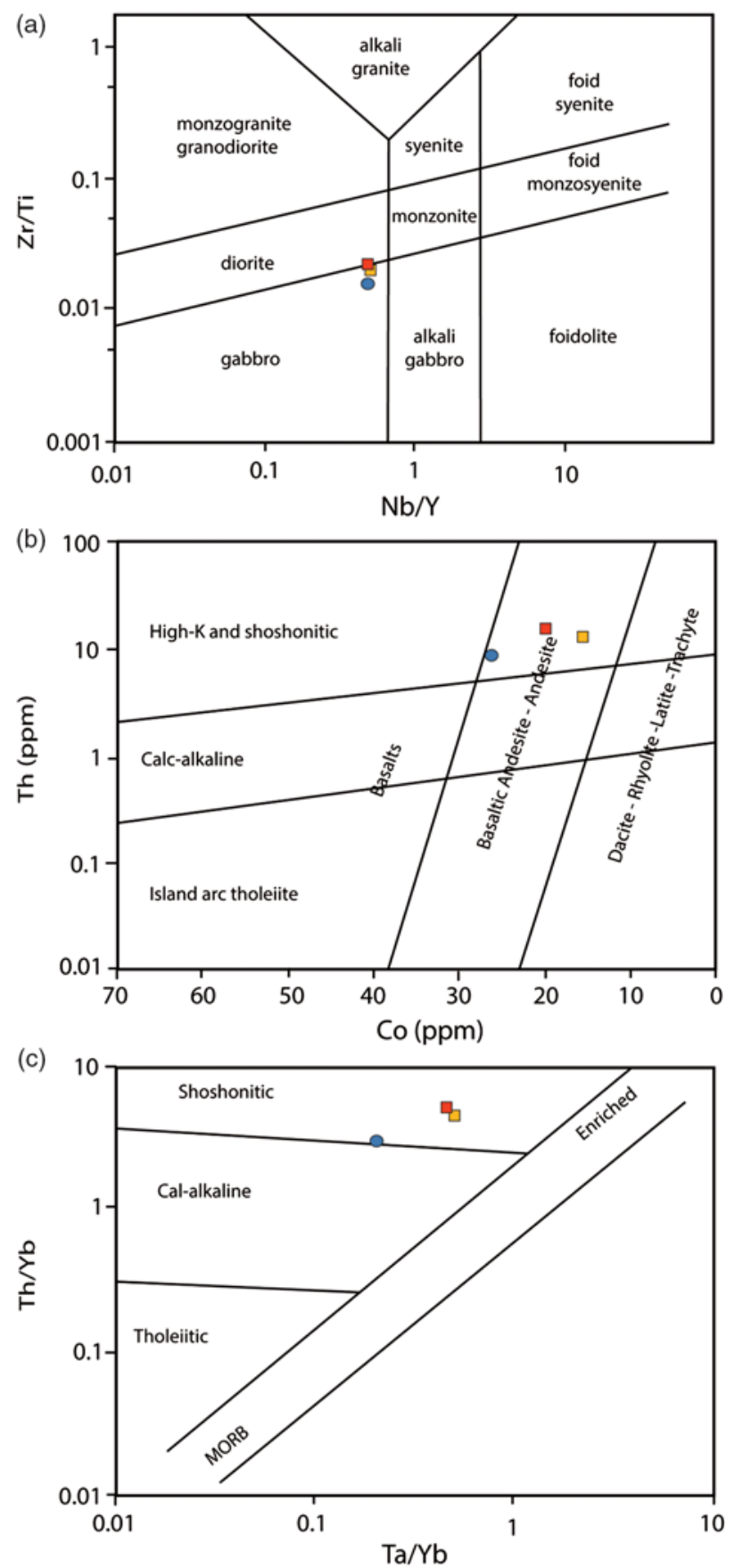

Fig. 8. (Colour online) (a) $\mathrm{Zr} / \mathrm{Ti}$ versus $\mathrm{Nb} / \mathrm{Y}$ diagram from Pearce (1996) modified after Winchester \& Floyd (1977). (b) Th-Co discriminant diagram for altered volcanic island arc rocks, using immobile trace elements, from Hastie et al. (2007). (c) Th/Yb versus Ta/ Yb diagram after Pearce (1983).

monazite analyses display a single alignment in the Concordia diagram and provide an intercept age of $20.7 \pm 0.19 \mathrm{Ma}$ (Fig. 11b). The xenotime analysis also plots along this alignment, suggesting that the monazite and xenotime are coeval. Two grains (mnz3 and mnz16) are significantly older with apparent ${ }^{206} \mathrm{~Pb}-$ ${ }^{238} \mathrm{U}$ ages ranging from $241.3 \pm 8.8 \mathrm{Ma}$ to $225.7 \pm 7.4 \mathrm{Ma}$ (Table 2; Fig. 11a). It is noteworthy that mnz16 displays a heterogeneous age distribution in which Miocene and older domains are present. The BSE imaging of this grain is not consistent with a core-like structure but, on the contrary, suggests recrystallization processes. On that basis, the c. $21 \mathrm{Ma}$ age is interpreted as reflecting monazite growth or resetting of the $\mathrm{U}-\mathrm{Pb}$ system of preexisting minerals under metamorphic conditions. Older ages are interpreted as partial updating of minerals that were most likely snatched from deep-seated material by the dioritic magma.

\section{4.c. Age interpretations}

Most of the dated minerals yield an age of c. $21 \mathrm{Ma}$. In the Ceuta Peninsula, this age is now well documented and is associated with the D3 tectonic event, developed at the boundary between amphibolite- and greenschist-facies conditions, and which corresponds to the development of ductile extension (Homonnay et al. 2018). Interestingly, in the investigated micro-diorite, the dated monazites and xenotime are systematically in textural equilibrium with the secondary metamorphic phases in the groundmass as well as in inclusions within magmatic minerals, the latter being totally replaced by muscovite and chlorite (Fig. 10d). Consequently, monazite ages at c. $21 \mathrm{Ma}$ cannot be interpreted as the ages of magma crystallization but, on the contrary, are related to the late-D3 stage of metamorphism characterized by metamorphic re-equilibration, associated with fluid circulation, during early Miocene time. Resetting of monazite ages during greenschist-facies metamorphism and related fluid activity is clearly demonstrated (e.g. Williams et al. 2011; SeydouxGuillaume et al. 2012) and was already outlined on metamorphic rocks from the Internal Rif (Montel et al. 2000; Janots et al. 2006; Michard et al. 2006; Negro et al. 2006; Chalouan et al. 2008; Rossetti et al. 2010; Gueydan et al. 2015; Homonnay et al. 2018) and also in the Internal Betic (Acosta-Vigil et al. 2014).

\section{Geological consequences}

We report for the first time the occurrence of calc-alkaline magmatic sills in the Ceuta Peninsula (Internal Rif). Sampled microdiorites and micro-gabbrodiorites show a primary magmatic mineralogy and a geochemical signature diagnostic for high-K calc-alkaline to shoshonitic island arc magmatism. Field observations based on geometric relationships between the micro-diorite sills and the main regional foliation S2, developed under intermediate-pressure granulite-facies conditions before $28 \mathrm{Ma}$ (Homonnay et al. 2018), demonstrate that the magmatic sills emplaced during the late stage of the D2 tectonic event. Furthermore, these magmatic rocks are fully metamorphosed under greenschist-facies metamorphic conditions. The latter, depicted at the regional scale, is coeval with an early Miocene D3 extensional tectonic event (Homonnay et al. 2018). Hence, syn- to late-D2 and pre-D3 magmatic sill emplacement is consistent with the magmatic monazite $\mathrm{U}-\mathrm{Pb}$ age resetting at $c$. $21 \mathrm{Ma}$.

The significance of this pre-Miocene high-K calc-alkaline magmatism must now be envisioned and discussed within the framework of the geodynamic context presently held for the Alboran domain. Following geophysical investigations, and particularly tomographic studies (Blanco \& Spakman, 1993; Gutscher et al. 2002; Timoulali et al. 2014; Villaseñor et al. 2015), the Betic-Rif orogen that surrounds the Alboran Basin is regarded as an emblematic example of a subduction-controlled orogeny followed by slab rollback leading to the opening of the Alboran back-arc basin (e.g. Faccenna et al. 2004; Spakman \& Wortel, 2004; Vergés \& Fernàndez, 2012; Bezada et al. 2013; Van Hinsbergen et al. 2014). In this geodynamic framework, slab rollback of the Tethyan oceanic 
(a)
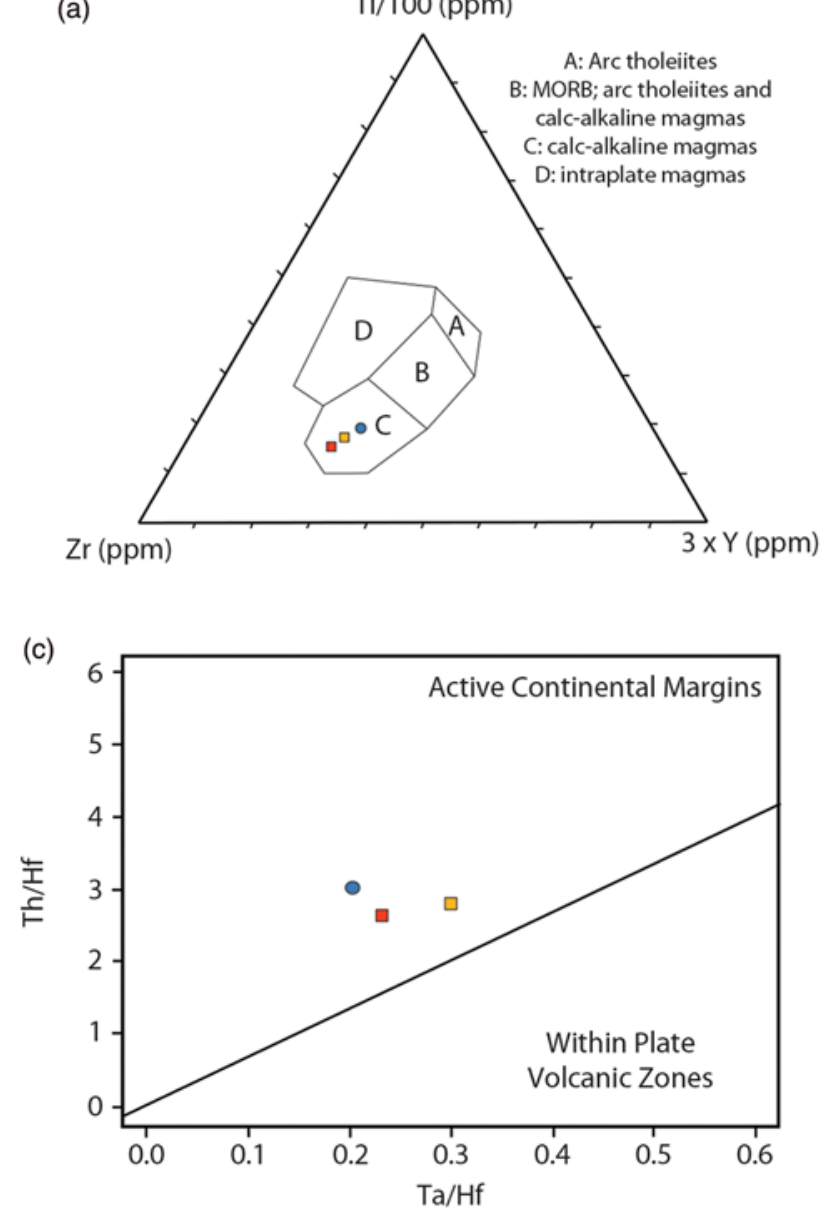

(b)
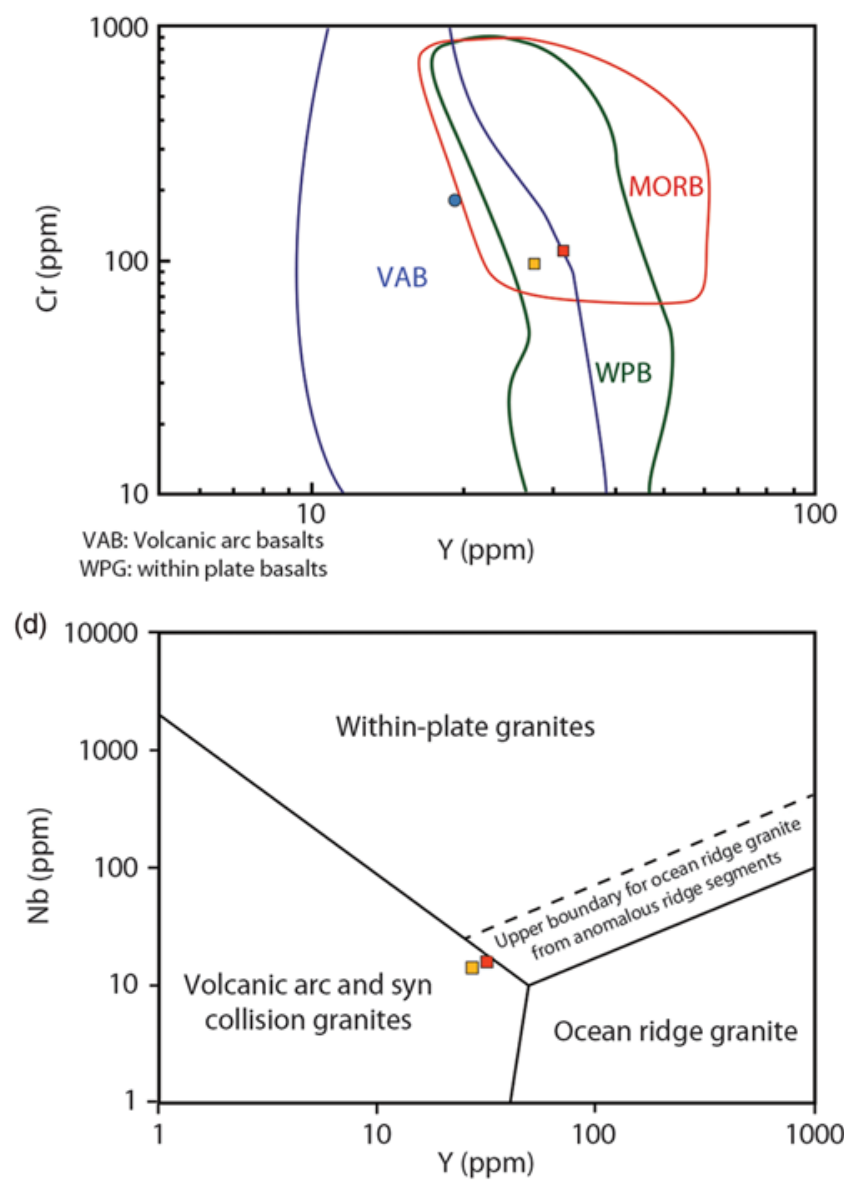

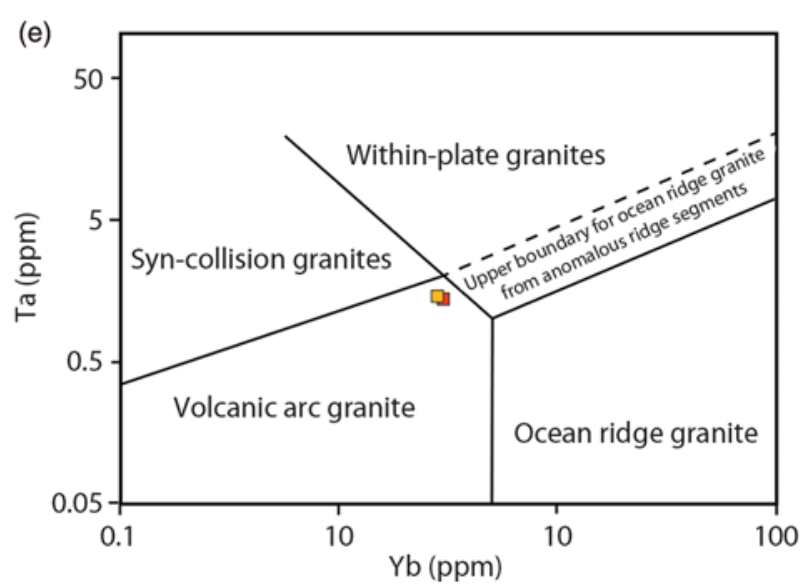

Fig. 9. (Colour online) (a) Ti/Zr/Y discriminant diagram from Pearce \& Cann (1973). A - field of island arc tholeiites; B - field of MORB, arc tholeiites and calc-alkaline magmas; C - field of calc-alkaline magmas; D - field of within-plate magmas. (b) Cr versus Y discriminant diagram between MORB, volcanic arc basalts (VAB) and within-plate basalts (WPB) from Pearce (1982). (c) Th/Hf versus Ta/Hf diagram from Schandl \& Gorton (2002). (d) Nb versus Y tectonic discriminant diagram for granitoid rocks (Pearce et al. 1984). (e) Ta versus Yb tectonic discriminant diagram for granitoid rocks (Pearce et al. 1984).

lithosphere initiated at c. 23-21 Ma, while the timing of the Alpine subduction is Eocene up to Oligocene. The occurrence of pre-Miocene high-K calc-alkaline to shoshonitic arc-related magmatism is clearly consistent with the nowadays-proposed geodynamic context and represents the last geological component, so far unknown, of the Alboran subduction system. In such a framework, the discovery of calc-alkaline magmatic sills allows the magmatic arc, and thus the upper plate of the subduction system, to be identified. In the case of the Rif belt, the Lower Sebtides should correspond to the upper plate of the subduction system. Such a pattern is consistent with the scenario recently proposed by Homonnay et al. (2018) for the development of high-temperature/intermediate- to low-pressure metamorphism within the lowermost Ceuta units (i.e. Lower Sebtides) interpreted as an orogenic wedge located, in a backward position, in the upper plate of the Alboran subduction zone. 

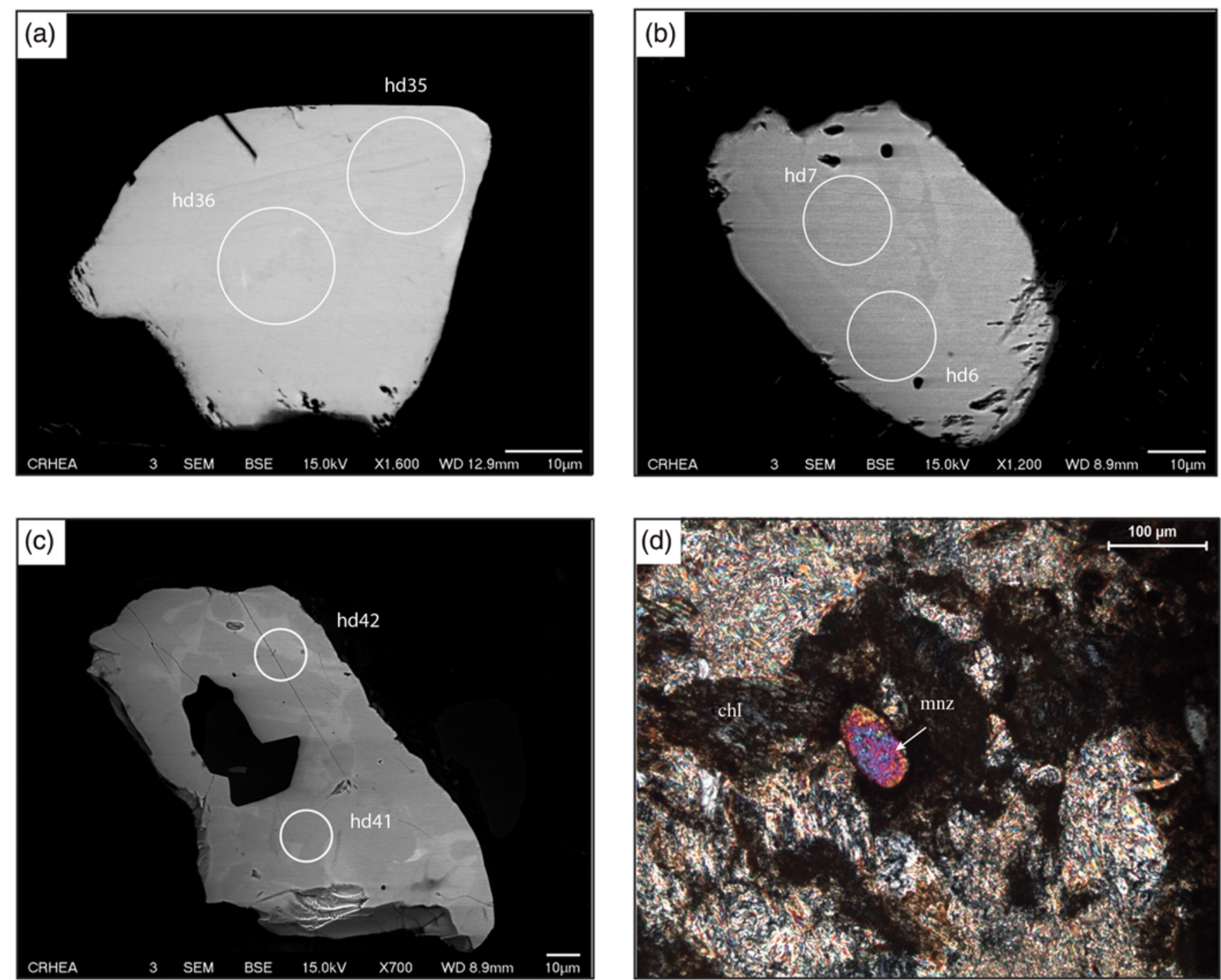

Fig. 10. (Colour online) Backscattered electron (BSE) and microscopic images of monazite grains in the micro-diorite sill. Locations of U-Th-Pb analyses are circled in BSE images. (a) Homogeneous monazite grain. (b) Monazite grain exhibiting light grey core and dark grey rim. (c) Monazite grain with light grey patches and inclusion. (d) Microscopic photo of a monazite (mnz3) surrounded by chlorite (chl) and muscovite (ms).

Our structural and geochronological data reveal that, in the Ceuta area, high-temperature metamorphism and calcalkaline magmatism are, at least in part, synchronous. This is consistent with the thermal behaviour of supra-subduction magmatic arcs. Indeed, in numerous examples of active or extinct arcs, regional metamorphism is coeval with arc building, and heat input is related to continuous or episodic emplacement of magmatic intrusions (Miyashiro, 1961; Ernst, 1975; Schiffman et al. 1984; Aguirre et al. 2000; Willner et al. 2004; Willner, 2005). The small volume of magmatic rocks identified up to now could be the result of a weakly productive magmatic arc or be the result of a difficulty in identifying these rocks in the field.

Furthermore, in the northern Rif, the Upper Sebtides located westward of the Ceuta Peninsula underwent an Oligocene highpressure/low-temperature metamorphism (Bouybaouene et al. 1995; Goffe et al. 1996; Michard et al. 1997; Janots et al. 2006) and thus must be considered as the lower plate subducted beneath the Lower Sebtides (Fig. 12). The tectonic coupling between the Upper and Lower Sebtides defines a typical example of 'paired metamorphic belts' (Brown, 2010 and references therein). Indeed, island arc and back-arc regions are recognized as a suitable tectonic setting for the development of regional high-temperature/ low-pressure metamorphism (Miyashiro, 1961; Oxburgh \& Turcotte, 1970; Ernst, 1973). This metamorphism developed in the upper plate of the subduction zone is the counterpart of the high-pressure/low-temperature metamorphism widespread within the down-going lower plate (Fig. 12).

After the development of the paired metamorphic belts, during early Miocene time, the Upper Sebtides underwent normal faulting associated with back-arc extension and opening of the Alboran Basin (Fig. 12; Comas et al. 1999; Platt et al. 2003; Martínez-García et al. 2017; Homonnay et al. 2018). Post-subduction deformation is thus observed in the studied area; however, this deformation is not strong enough to reverse the initial relationships between the Upper and Lower Sebtides. 
Table 2. Results of the U-Th-Pb LA-ICP-MS analysis of monazite and xenotime from the micro-diorite sill SEB12-04

\begin{tabular}{|c|c|c|c|c|c|c|c|c|c|c|c|c|c|c|c|c|c|}
\hline \multirow[b]{2}{*}{ Analyses } & & \multirow[b]{2}{*}{$\begin{array}{c}\mathrm{Pb}^{\star} \\
(\mathrm{ppm})\end{array}$} & \multirow[b]{2}{*}{$\begin{array}{c}\text { Th } \\
\text { (ppm) }\end{array}$} & \multirow[b]{2}{*}{$\underset{(\mathrm{ppm})}{U}$} & \multirow[b]{2}{*}{$\begin{array}{c}\text { Th/ } \\
\text { U }\end{array}$} & \multirow[b]{2}{*}{$\begin{array}{l}{ }^{208} \mathrm{~Pb} / \\
{ }^{206} \mathrm{~Pb}\end{array}$} & \multirow[b]{2}{*}{$\begin{array}{c}{ }^{207} \mathrm{~Pb} / \\
{ }^{206} \mathrm{~Pb}\end{array}$} & \multirow[b]{2}{*}{$\pm(1 \sigma)$} & \multirow[b]{2}{*}{$\begin{array}{l}{ }^{207} \mathrm{~Pb} / \\
{ }^{235} \mathrm{U}\end{array}$} & \multirow[b]{2}{*}{$\pm(1 \sigma)$} & \multirow[b]{2}{*}{$\begin{array}{c}{ }^{206} \mathrm{~Pb} / \\
{ }^{238} \mathrm{U}\end{array}$} & \multirow[b]{2}{*}{$\pm(1 \sigma)$} & \multirow[b]{2}{*}{ Rho } & \multicolumn{4}{|c|}{ Apparent ages (Ma) } \\
\hline & & & & & & & & & & & & & & $\begin{array}{l}{ }^{206} \mathrm{~Pb} / \\
{ }^{238} \mathrm{U}\end{array}$ & $\begin{array}{c} \pm \\
(1 \sigma)\end{array}$ & $\begin{array}{l}{ }^{207} \mathrm{~Pb} / \\
{ }^{206} \mathrm{~Pb}\end{array}$ & $\begin{array}{c} \pm(1 \\
\sigma)\end{array}$ \\
\hline \multicolumn{18}{|c|}{ Micro-diorite sill SEB12-04 } \\
\hline \multicolumn{18}{|l|}{ Monazite } \\
\hline hd1 & $\mathrm{mnz} 1$ & 81 & 18190 & 1811 & 10.04 & 2.307 & 0.0564 & 0.0037 & 0.0247 & 0.0015 & 0.0032 & 0.0001 & 0.42 & 20.5 & 0.5 & 467.8 & 137.3 \\
\hline hd2 & mnz1 & 78 & 17056 & 1837 & 9.29 & 2.130 & 0.0564 & 0.0036 & 0.0245 & 0.0014 & 0.0032 & 0.0001 & 0.43 & 20.3 & 0.5 & 467.0 & 134.4 \\
\hline hd3 & $\mathrm{mnz1}$ & 95 & 20689 & 2256 & 9.17 & 2.092 & 0.0541 & 0.0032 & 0.0238 & 0.0013 & 0.0032 & 0.0001 & 0.40 & 20.5 & 0.4 & 376.9 & 127.4 \\
\hline hd4 & mnz1 & 98 & 21077 & 2284 & 9.23 & 2.200 & 0.0590 & 0.0033 & 0.0253 & 0.0013 & 0.0031 & 0.0001 & 0.43 & 20.1 & 0.4 & 566.7 & 117.7 \\
\hline hd5 & $\mathrm{mnz2}$ & 88 & 20155 & 2284 & 8.82 & 1.848 & 0.0623 & 0.0035 & 0.0271 & 0.0014 & 0.0032 & 0.0001 & 0.49 & 20.3 & 0.5 & 682.7 & 115.4 \\
\hline hd6 & $\mathrm{mnz3}$ & 1287 & 21068 & 3370 & 6.25 & 1.916 & 0.0532 & 0.0019 & 0.2612 & 0.0086 & 0.0356 & 0.0006 & 0.51 & 225.7 & 3.7 & 335.6 & 79.4 \\
\hline hd7 & $\mathrm{mnz3}$ & 964 & 19146 & 2862 & 6.69 & 1.812 & 0.0532 & 0.0022 & 0.2799 & 0.0105 & 0.0381 & 0.0007 & 0.50 & 241.3 & 4.4 & 339.0 & 89.8 \\
\hline hd8 & $\mathrm{mnz4}$ & 85 & 19588 & 1834 & 10.68 & 2.318 & 0.0545 & 0.0038 & 0.0250 & 0.0016 & 0.0033 & 0.0001 & 0.42 & 21.4 & 0.6 & 390.9 & 149.0 \\
\hline hd9 & $\mathrm{mnz5}$ & 121 & 24339 & 3111 & 7.82 & 1.832 & 0.0553 & 0.0028 & 0.0248 & 0.0012 & 0.0033 & 0.0001 & 0.46 & 21.0 & 0.4 & 424.0 & 109.2 \\
\hline hd10 & $\mathrm{mnz5}$ & 103 & 21187 & 2266 & 9.35 & 2.333 & 0.0569 & 0.0036 & 0.0261 & 0.0015 & 0.0033 & 0.0001 & 0.41 & 21.4 & 0.5 & 485.7 & 135.1 \\
\hline hd11 & mnz6 & 115 & 17483 & 1713 & 10.20 & 1.842 & 0.2865 & 0.0090 & 0.1841 & 0.0072 & 0.0047 & 0.0001 & 0.60 & 30.0 & 0.7 & 3398.4 & 48.1 \\
\hline $\mathrm{hd} 12$ & $\mathrm{mnz6}$ & 112 & 19587 & 3038 & 6.45 & 1.469 & 0.1229 & 0.0045 & 0.0585 & 0.0018 & 0.0035 & 0.0001 & 0.65 & 22.2 & 0.4 & 1998.7 & 63.9 \\
\hline hd13 & $\mathrm{mnz6}$ & 74 & 15998 & 1801 & 8.88 & 1.854 & 0.0719 & 0.0055 & 0.0322 & 0.0022 & 0.0033 & 0.0001 & 0.49 & 20.9 & 0.7 & 982.3 & 148.0 \\
\hline hd14 & $\mathrm{mnz6}$ & 90 & 17235 & 1884 & 9.15 & 1.913 & 0.1803 & 0.0070 & 0.0941 & 0.0030 & 0.0038 & 0.0001 & 0.76 & 24.4 & 0.6 & 2655.5 & 63.3 \\
\hline hd15 & $\mathrm{mnz} 7$ & 87 & 16529 & 1196 & 13.82 & 2.450 & 0.3686 & 0.0124 & 0.2724 & 0.0116 & 0.0054 & 0.0001 & 0.61 & 34.5 & 0.9 & 3785.8 & 50.2 \\
\hline hd16 & $\mathrm{mnz8}$ & 115 & 19453 & 3974 & 4.89 & 1.150 & 0.0512 & 0.0025 & 0.0232 & 0.0010 & 0.0033 & 0.0001 & 0.48 & 21.1 & 0.4 & 251.6 & 107.7 \\
\hline hd17 & $\mathrm{mnz} 9$ & 101 & 23785 & 2712 & 8.77 & 1.847 & 0.0529 & 0.0032 & 0.0232 & 0.0013 & 0.0032 & 0.0001 & 0.45 & 20.4 & 0.5 & 324.9 & 131.0 \\
\hline hd18 & $\mathrm{mnz} 9$ & 141 & 34361 & 3028 & 11.35 & 2.520 & 0.0584 & 0.0031 & 0.0255 & 0.0012 & 0.0032 & 0.0001 & 0.46 & 20.4 & 0.4 & 543.7 & 111.0 \\
\hline hd19 & $\mathrm{mnz} 9$ & 110 & 25980 & 2610 & 9.95 & 2.195 & 0.0561 & 0.0034 & 0.0245 & 0.0014 & 0.0032 & 0.0001 & 0.45 & 20.4 & 0.5 & 454.7 & 129.2 \\
\hline hd20 & mnz10 & 63 & 14931 & 1555 & 9.60 & 2.087 & 0.0559 & 0.0059 & 0.0256 & 0.0025 & 0.0033 & 0.0001 & 0.40 & 21.4 & 0.8 & 447.6 & 218.2 \\
\hline hd21 & mnz10 & 52 & 12453 & 1315 & 9.47 & 1.816 & 0.0845 & 0.0064 & 0.0391 & 0.0027 & 0.0034 & 0.0001 & 0.48 & 21.6 & 0.7 & 1304.8 & 140.6 \\
\hline hd24 & mnz11 & 93 & 22018 & 1869 & 11.78 & 2.567 & 0.1194 & 0.0061 & 0.0595 & 0.0026 & 0.0036 & 0.0001 & 0.64 & 23.2 & 0.6 & 1947.1 & 87.9 \\
\hline hd25 & $\mathrm{mnz} 11$ & 78 & 21998 & 1951 & 11.27 & 2.016 & 0.0566 & 0.0040 & 0.0253 & 0.0017 & 0.0032 & 0.0001 & 0.42 & 20.9 & 0.6 & 474.0 & 150.7 \\
\hline hd26 & $\mathrm{mnz} 12$ & 93 & 23475 & 1865 & 12.58 & 2.629 & 0.0556 & 0.0040 & 0.0256 & 0.0017 & 0.0033 & 0.0001 & 0.44 & 21.5 & 0.6 & 437.2 & 154.0 \\
\hline hd27 & $\mathrm{mnz} 12$ & 85 & 23377 & 1646 & 14.20 & 2.852 & 0.0591 & 0.0044 & 0.0266 & 0.0018 & 0.0033 & 0.0001 & 0.44 & 21.0 & 0.6 & 568.9 & 153.4 \\
\hline hd28 & $\mathrm{mnz} 12$ & 96 & 22094 & 2583 & 8.55 & 1.777 & 0.0533 & 0.0033 & 0.0241 & 0.0014 & 0.0033 & 0.0001 & 0.42 & 21.2 & 0.5 & 339.5 & 134.6 \\
\hline hd29 & $\mathrm{mnz} 13$ & 135 & 26692 & 4677 & 5.71 & 1.152 & 0.0513 & 0.0024 & 0.0239 & 0.0010 & 0.0034 & 0.0001 & 0.48 & 21.8 & 0.4 & 254.3 & 103.3 \\
\hline hd30 & mnz13 & 96 & 23562 & 2602 & 9.06 & 2.13 & 0.0533 & 0.0036 & 0.0235 & 0.0015 & 0.0032 & 0.0001 & 0.40 & 20.5 & 0.5 & 341.2 & 146.1 \\
\hline hd31 & $\mathrm{mnz} 13$ & 98 & 21636 & 2899 & 7.46 & 1.629 & 0.0582 & 0.0035 & 0.0260 & 0.0014 & 0.0032 & 0.0001 & 0.45 & 20.8 & 0.5 & 538.1 & 125.3 \\
\hline hd35 & $\mathrm{mnz14}$ & 93 & 18292 & 1325 & 13.81 & 2.092 & 0.4427 & 0.0150 & 0.4138 & 0.0178 & 0.0068 & 0.0002 & 0.62 & 43.6 & 1.2 & 4060.8 & 49.7 \\
\hline hd36 & mnz14 & 99 & 27952 & 1983 & 14.10 & 2.929 & 0.0681 & 0.0051 & 0.0304 & 0.0021 & 0.0032 & 0.0001 & 0.44 & 20.9 & 0.6 & 870.1 & 148.3 \\
\hline hd37 & $\mathrm{mnz} 15$ & 46 & 7062 & 413 & 17.08 & 1.897 & 0.4815 & 0.0406 & 0.4833 & 0.0521 & 0.0073 & 0.0005 & 0.62 & 46.8 & 3.1 & 4185.5 & 119.3 \\
\hline hd38 & mnz15 & 62 & 21438 & 1182 & 18.14 & 3.020 & 0.0572 & 0.0067 & 0.0258 & 0.0028 & 0.0033 & 0.0001 & 0.36 & 21.0 & 0.8 & 498.1 & 237.9 \\
\hline hd39 & mnz15 & 66 & 20075 & 1302 & 15.42 & 2.880 & 0.0789 & 0.0066 & 0.0359 & 0.0027 & 0.0033 & 0.0001 & 0.48 & 21.2 & 0.8 & 1169.4 & 158.2 \\
\hline hd41 & $\mathrm{mnz} 16$ & 87 & 25496 & 2086 & 12.22 & 2.229 & 0.0571 & 0.0047 & 0.0264 & 0.0020 & 0.0034 & 0.0001 & 0.39 & 21.6 & 0.6 & 496.6 & 170.6 \\
\hline hd42 & mnz16 & 2266 & 41967 & 2118 & 19.81 & 7.007 & 0.0559 & 0.0024 & 0.2917 & 0.0116 & 0.0378 & 0.0008 & 0.51 & 239.4 & 4.8 & 448.4 & 92.7 \\
\hline hd43 & $\mathrm{mnz} 17$ & 125 & 29677 & 3832 & 7.75 & 1.575 & 0.0535 & 0.0031 & 0.0243 & 0.0013 & 0.0033 & 0.0001 & 0.45 & 21.2 & 0.5 & 350.1 & 125.9 \\
\hline hd44 & $\mathrm{mnz} 18$ & 84 & 21465 & 2129 & 10.08 & 2.083 & 0.0555 & 0.0050 & 0.0253 & 0.0022 & 0.0033 & 0.0001 & 0.36 & 21.3 & 0.6 & 432.0 & 188.4 \\
\hline hd45 & $\mathrm{mnz} 18$ & 81 & 23903 & 2443 & 9.79 & 1.622 & 0.0527 & 0.0045 & 0.0238 & 0.0019 & 0.0033 & 0.0001 & 0.34 & 21.0 & 0.6 & 315.5 & 183.0 \\
\hline \multicolumn{18}{|l|}{ Xenotime } \\
\hline hd32 & xen1 & 25 & 624 & 1859 & 0.34 & 0.039 & 0.0467 & 0.0038 & 0.0216 & 0.0017 & 0.0034 & 0.0001 & 0.39 & 21.6 & 0.6 & 33.9 & 185.5 \\
\hline hd33 & xen1 & 27 & 638 & 1891 & 0.34 & 0.107 & 0.0495 & 0.0041 & 0.0229 & 0.0018 & 0.0034 & 0.0001 & 0.38 & 21.6 & 0.6 & 169.7 & 184.2 \\
\hline
\end{tabular}

$\mathrm{Pb}^{\star}$ - radiogenic lead. 

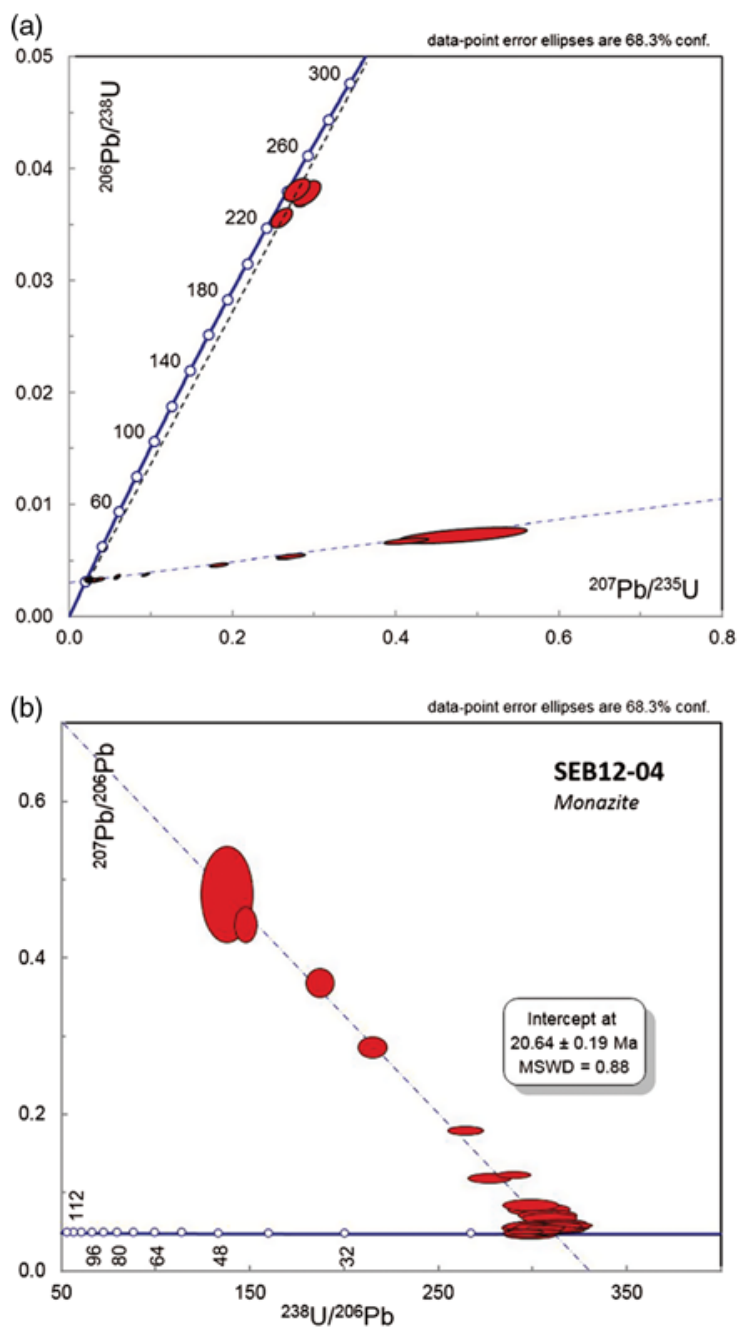

Fig. 11. (Colour online) (a) Concordia diagram for $\mathrm{U}-\mathrm{Pb}$ analyses on monazites and xenotime. (b) Tera-Wasserburg diagram close-up of young U-Pb analyses.
At the scale of the Betic-Rif orogen, published magmatic studies mostly deal with recent magmatic episodes within the Neogene volcanic province widespread in the eastern part of the Alboran domain (Duggen et al. 2008; see Lustrino et al. 2011 for a review). Up to now, earlier magmatic events were only described in the Betic Cordilleras (e.g. Bellon et al. 1983; Torres-Roldan et al. 1986; Turner et al. 1999; Duggen et al. 2004; Lustrino et al. 2011; Esteban et al. 2013) and more precisely in the Malaga area (SW Betic), as tholeiitic and calc-alkaline basaltic andesite dykes. $\mathrm{K}-\mathrm{Ar}$ and $\mathrm{Ar}-\mathrm{Ar}$ geochronological investigations on these rocks reveal two age groups: (1) 30-38 Ma, which corresponds to calcalkaline dyke emplacement during the subduction process, and (2) 17.4-19.8 Ma, interpreted as $\mathrm{K}-\mathrm{Ar}$ system resetting due to a wide-scale thermal event. Furthermore, a high-K to shoshonitic magmatic episode occurred between 16 and $8 \mathrm{Ma}$, in the eastern Rif and Betics and in the Alboran Sea. It is related to the slab rollback and marks the position of the deep subducted lithosphere beneath the Alboran Basin (Gill et al. 2004; Duggen et al. 2005).

The new data we obtained in the northern Rif are in agreement with this interpretation proposed for the Betic chains, and all together support a model of subduction-related orogeny for the Betic/Rif Cordilleras.

\section{Conclusions}

We described for the first time a high-K calc-alkaline magmatism in the Lower Sebtides (Internal Rif). Our structural and petrographic observations with geochronological data demonstrate that: (i) pre-Miocene high-K calc-alkaline to shoshonitic micro-diorite sills emplaced in the Ceuta Peninsula within the Lower Sebtides (Internal Rif) during high-temperature/medium-pressure metamorphism (i.e. D2 deformation event); (ii) these newly recognized magmatic rocks have a primary magmatic mineralogy and geochemical signature diagnostic of island arc magmatism; (iii) the micro-diorite sills display a secondary medium-temperature/ low-pressure metamorphic episode (i.e. D3 deformation event), which led to monazite $\mathrm{U}-\mathrm{Pb}$ age resetting at $c .21 \mathrm{Ma}$.

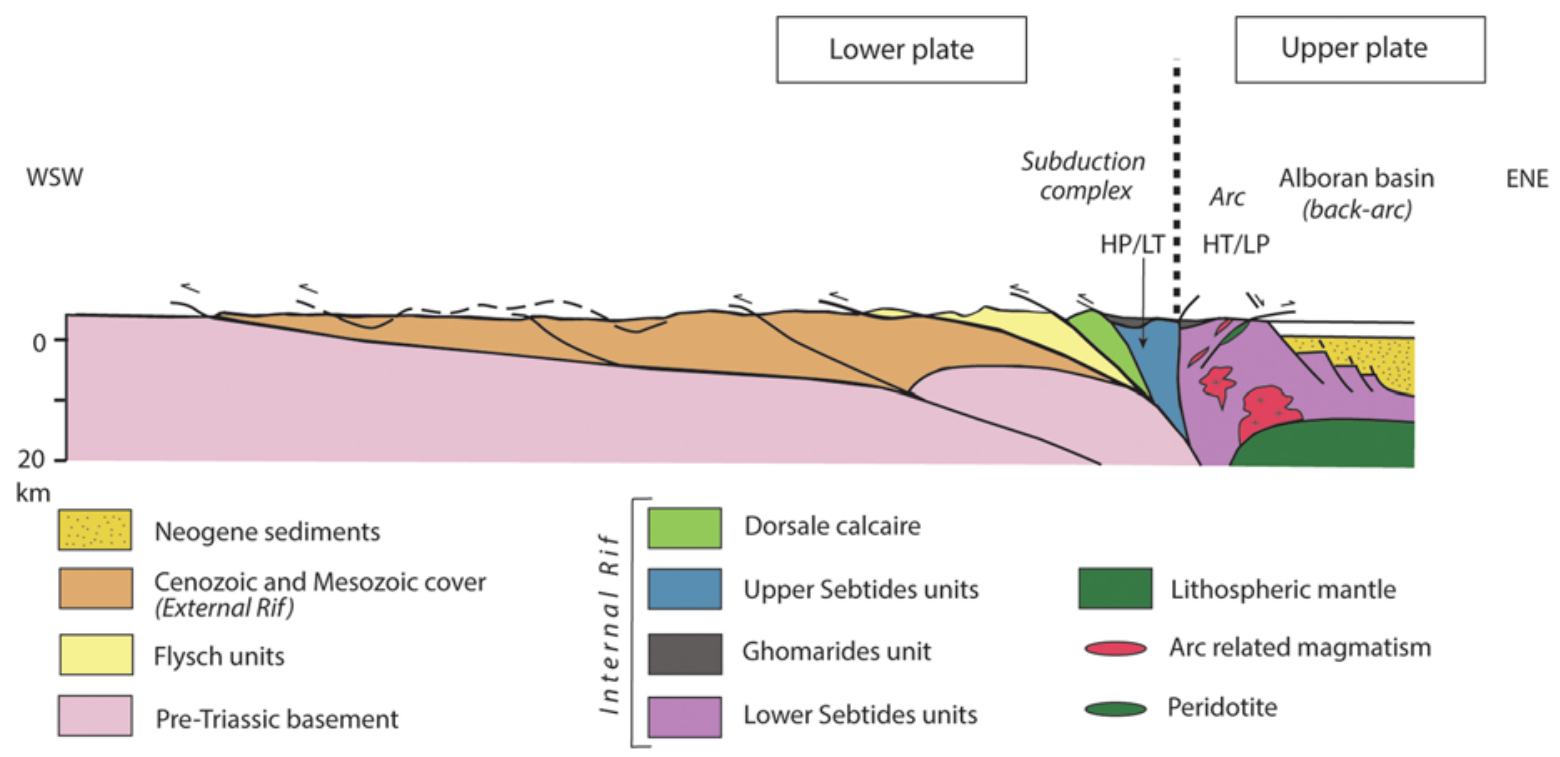

Fig. 12. (Colour online) Schematic cross-section of the Rif belt (modified from Chalouan et al. 2008). HP/LT: high pressure/ low temperature. HT/LP: high temperature/ low pressure. 
The presence of arc-related magmatism, probably Oligocene in age, is not surprising in the nowadays widely accepted subduction system for the Gibraltar arc formation. Therefore, in such a framework, the so-called Lower Sebtides correspond to the upper plate of the subduction system, whereas the Upper Sebtides may be considered as the lower plate of the subduction system.

Acknowledgements. The field work was supported by the FP7-IRSESMEDYNA project.

\section{References}

Acosta-Vigil A, Rubatto D, Bartoli O, Cesare B, Meli S, Pedrera A, Azor A and Tajčmanová L (2014) Age of anatexis in the crustal footwall of the Ronda peridotites, S Spain. Lithos 210-211, 147-67.

Ague JJ (1994) Mass transfer during Barrovian metamorphism of pelites, southcentral Connecticut; I, Evidence for changes in composition and volume. American Journal of Science 294, 989-1057.

Ague JJ (2003) Fluid infiltration and transport of major, minor, and trace elements during regional metamorphism of carbonate rocks, Wepawaug Schist, Connecticut, USA. American Journal of Science 303, 753-816.

Aguirre L, Robinson D, Bevins RE, Morata D, Vergara M, Fonseca E and Carrasco J (2000) A low-grade metamorphic model for the Miocene volcanic sequences in the Andes of central Chile. New Zealand Journal of Geology and Geophysics 43, 83-93.

Barbarin B (1990) Granitoids: main petrogenetic classifications in relation to origin and tectonic setting. Geological Journal 25, 227-38.

Beccaluva L, Bianchini G and Wilson M eds (2007) Cenozoic Volcanism in the Mediterranean Area. Geological Society of America Special Papers no. 418, $358 \mathrm{pp}$.

Bellon H, Bordet P and Montenat C (1983) Chronologie du magmatisme Neogene des Cordilleres Betiques (Espagne meridionale). Bulletin de la Société géologique de France S7-XXV, 205-17.

Bezada MJ, Humphreys ED, Toomey DR, Harnafi M, Dávila JM and Gallart J (2013) Evidence for slab rollback in westernmost Mediterranean from improved upper mantle imaging. Earth and Planetary Science Letters 368, $51-60$.

Blanco MJ and Spakman W (1993) The P-wave velocity structure of the mantle below the Iberian Peninsula: evidence for subducted lithosphere below southern Spain. Tectonophysics 221, 13-34.

Bosch D, Garrido CJ, Bruguier O, Dhuime B, Bodinier J-L, Padròn-Navarta JA and Galland B (2011) Building an island-arc crustal section: time constraints from a LA-ICP-MS zircon study. Earth and Planetary Science Letters 309, 268-79.

Bosch D, Hammor D, Bruguier O, Caby R and Luck J-M (2002) Monazite "in situ" ${ }^{207} \mathrm{~Pb} /{ }^{206} \mathrm{~Pb}$ geochronology using a small geometry high-resolution ion probe. Application to Archaean and Proterozoic rocks. Chemical Geology 184, 151-65.

Bouybaouene ML, Goffé B and Michard A (1995) High-pressure, low-temperature metamorphism in the Sebtides nappes, northern Rif, Morocco Geogaceta 17, 117-19.

Brewer TS and Menuge JF (1998) Metamorphic overprinting of Sm-Nd isotopic systems in volcanic rocks: the Telemark Supergroup, southern Norway. Chemical Geology 145, 1-16.

Bridgwater D ed. (1989) Fluid Movements - Element Transport and the Composition of the Deep Crust. Dordrecht: Springer Netherlands, 415 pp.

Brown M (2010) Paired metamorphic belts revisited. Gondwana Research 18, 46-59.

Bruguier O, Hammor D, Bosch D and Caby R (2009) Miocene incorporation of peridotite into the Hercynian basement of the Maghrebides (Edough massif, NE Algeria): implications for the geodynamic evolution of the Western Mediterranean. Chemical Geology 261, 171-83.

Carignan J, Hild P, Mevelle G, Morel J and Yeghicheyan D (2001) Routine analyses of trace elements in geological samples using flow injection and low pressure on-line liquid chromatography coupled to ICP-MS: a study of geochemical reference materials BR, DR-N, UB-N, AN-G and GH. Geostandards and Geoanalytical Research 25, 187-98.
Carminati E, Lustrino M and Doglioni C (2012) Geodynamic evolution of the central and western Mediterranean: tectonics vs. igneous petrology constraints. Tectonophysics 579, 173-92.

Chalouan A, Michard A, Feinberg H, Montigny R and Saddiqi O (2001) The Rif mountain building (Morocco): a new tectonic scenario. Bulletin de la Société géologique de France 172, 603-16.

Chalouan A, Michard A, Kadiri KEL, Negro F, Frizon de Lamotte D, Soto JI and Saddiqi $\mathbf{O}$ (2008) The Rif belt. In Lecture Notes in Earth Sciences (ed. A Michard), pp. 203-302. Berlin: Springer.

Comas MC, Platt JP, Soto JI and Watts AB (1999) The origin and tectonic history of the Alboran Basin: insights from leg 161 results. In Proceedings of the Ocean Drilling Program, Scientific Results, vol. 161 (eds R Zahn, MC Comas and A Klaus), pp. 555-80. College Station, Texas.

Conticelli S, Guarnieri L, Farinelli A, Mattei M, Avanzinelli R, Bianchini G, Boari E, Tommasini S, Tiepolo M, Prelević D and Venturelli G (2009) Trace elements and $\mathrm{Sr}-\mathrm{Nd}-\mathrm{Pb}$ isotopes of K-rich, shoshonitic, and calc-alkaline magmatism of the Western Mediterranean Region: genesis of ultrapotassic to calc-alkaline magmatic associations in a post-collisional geodynamic setting. Lithos 107, 68-92.

Cox KG, Bell JD and Pankhurst RJ (1979) The Interpretation of Igneous Rocks. London: George Allen \& Unwin.

Duggen S, Hoernle K, Klügel A, Geldmacher J, Thirlwall M, Hauff F, Lowry D and Oates N (2008) Geochemical zonation of the Miocene Alboran Basin volcanism (westernmost Mediterranean): geodynamic implications. Contributions to Mineralogy and Petrology 156, 577-93.

Duggen S, Hoernle $K$, van den Bogaard $P$ and Garbe-Schönberg D (2005) Post-collisional transition from subduction- to intraplate-type magmatism in the westernmost Mediterranean: evidence for continental-edge delamination of subcontinental lithosphere. Journal of Petrology 46, 1155-201.

Duggen S, Hoernle K, van den Bogaard P and Harris C (2004) Magmatic evolution of the Alboran region: the role of subduction in forming the western Mediterranean and causing the Messinian Salinity Crisis. Earth and Planetary Science Letters 218, 91-108.

Ernst WG (1973) Blueschist metamorphism and P-T regimes in active subduction zones. Tectonophysics 17, 255-72.

Ernst WG (1975) Systematics of large-scale tectonics and age progressions in Alpine and Circum-Pacific blueschist belts. Tectonophysics 26, $229-46$.

Esteban JJ, Tubía JM, Cuevas J, Seward D, Larionov A, Sergeev S and Navarro-Vilá F (2013) Insights into extensional events in the Betic Cordilleras, southern Spain: new fission-track and U-Pb SHRIMP analyses. Tectonophysics 603, 179-88.

Faccenna C, Becker TW, Auer L, Billi A, Boschi L, Brun JP, Capitanio FA, Funiciello F, Horvàth F, Jolivet L, Piromallo C, Royden L, Rossetti F and Serpelloni E (2014) Mantle dynamics in the Mediterranean. Reviews of Geophysics 52, 283-332.

Faccenna C, Becker TW, Lucente FP, Jolivet L and Rossetti F (2001) History of subduction and back-arc extension in the Central Mediterranean. Geophysical Journal International 145, 809-20.

Faccenna C, Piromallo C, Crespo-Blanc A, Jolivet L and Rossetti F (2004) Lateral slab deformation and the origin of the western Mediterranean arcs. Tectonics 23, TC1012, doi: 10.1029/2002TC001488.

Faccenna C, Speranza F, Caracciolo FD, Mattei M and Oggiano G (2002) Extensional tectonics on Sardinia (Italy): insights into the arc-back-arc transitional regime. Tectonophysics 356, 213-32.

Ferry JM (1994) A historical review of metamorphic fluid flow. Journal of Geophysical Research 99, 15487-98.

Frost BR, Barnes CG, Collins WJ, Arculus RJ, Ellis DJ and Frost CD (2001) A geochemical classification for granitic rocks. Journal of Petrology 42, $2033-48$.

Gill RCO, Aparicio A, El Azzouzi M, Hernandez J, Thirlwall MF, Bourgois J and Marriner GF (2004) Depleted arc volcanism in the Alboran Sea and shoshonitic volcanism in Morocco: geochemical and isotopic constraints on Neogene tectonic processes. Lithos 78, 363-88.

Goffe B, Azanon JM, Bouybaouene ML and Jullien M (1996) Metamorphic cookeite in Alpine metapelites from Rif, northern Morocco, and the Betic Chain, southern Spain. European Journal of Mineralogy 8, 335-48. 
Gueydan F, Pitra P, Afiri A, Poujol M, Essaifi A and Paquette JL (2015) Oligo-Miocene thinning of the Beni Bousera peridotites and their Variscan crustal host rocks, Internal Rif, Morocco. Tectonics 34, 1244-68.

Gutscher MA, Malod J, Rehault JP, Contrucci I, Klingelhoefer F, MendesVictor L and Spakman W (2002) Evidence for active subduction beneath Gibraltar. Geology 30, 1071-74.

Hastie AR, Kerr AC, Pearce JA and Mitchell SF (2007) Classification of altered volcanic island arc rocks using immobile trace elements: development of the Th-Co discrimination diagram. Journal of Petrology 48, 2341-57.

Homonnay E, Corsini M, Lardeaux JM, Romagny A, Münch P, Bosch D, Cenki-Tok B and Ouazzani-Touhami M (2018) Miocene crustal extension following thrust tectonic in the Lower Sebtides units (internal Rif, Ceuta Peninsula, Spain): implication for the geodynamic evolution of the Alboran domain. Tectonophysics 722, 507-35.

Janots E, Negro F, Brunet F, Goffé B, Engi M \& Bouybaouène ML (2006) Evolution of the REE mineralogy in HP-LT metapelites of the Sebtide complex, Rif, Morocco: monazite stability and geochronology. Lithos 87, 214-34.

Jolivet L and Brun J-P (2010) Cenozoic geodynamic evolution of the Aegean. International Journal of Earth Sciences 99, 109-38.

Jolivet L, Faccenna C, Huet B, Labrousse L, Le Pourhiet L, Lacombe O, Lecomte E, Burov E, Denèle Y, Brun J-P, Philippon M, Paul A, Salaün G, Karabulut H, Piromallo C, Monié P, Gueydan F, Okay AI, Oberhänsli R, Pourteau A, Augier R, Gadenne L and Driussi O (2013) Aegean tectonics: strain localisation, slab tearing and trench retreat. Tectonophysics 597-598, 1-33.

Kornprobst J (1974) Contribution à l'étude pétrographique et structurale de la zone interne du Rif (Maroc septentrional). Notes Mémoires du Service Géologique du Maroc, Rabat 251, 256 pp.

Lawrie KC (1992) Geochemical characterisation of a polyphase deformed, altered, and high grade metamorphosed volcanic terrane: implications for the tectonic setting of the Svecofennides, south-central Finland. Precambrian Research 59, 171-205.

Le Maitre RW, Bateman P, Dudek A, Keller J, Lameyre J, Le Bas MJ, Sabine PA, Schmid R, Sorensen H, Streickeisen A, Woolley A and Zanettin B (1989) Igneous Rocks: A Classification and Glossary of Terms (Subcommission ed. RW Le Maitre). Oxford: Blackwell Scientific Publications, 193 pp.

Lonergan L and White N (1997) Origin of the Betic-Rif mountain belt. Tectonics 16, 504-22.

Ludwig KR (2003) Mathematical-statistical treatment of data and errors for ${ }^{230} \mathrm{Th} / \mathrm{U}$ geochronology. Reviews in Mineralogy and Geochemistry 52, 631-56.

Lustrino M, Duggen S and Rosenberg CL (2011) The Central-Western Mediterranean: anomalous igneous activity in an anomalous collisional tectonic setting. Earth-Science Reviews 104, 1-40.

Martínez-García P, Comas M, Lonergan L and Watts AB (2017) From extension to shortening: tectonic inversion distributed in time and space in the Alboran Sea, Western Mediterranean. Tectonics 36, 2777-805.

Masters RL and Ague JJ (2005) Regional-scale fluid flow and element mobility in Barrow's metamorphic zones, Stonehaven, Scotland. Contributions to Mineralogy and Petrology 150, 1-18.

Michard A, Goffe B, Bouybaouene ML and Saddiqi O (1997) Late HercynianMesozoic thinning in the Alboran domain: metamorphic data from the northern Rif, Morocco. Terra Nova 9, 171-4.

Michard A, Goffe B, Chalouan A and Saddiqi O (1991) The correlations between the Rifan-Betic Mountain Belt and the Alps, and their consequences. Bulletin de la Societe geologique de France 162, 1151-60.

Michard A, Negro F, Saddiqi O, Bouybaouene ML, Chalouan A, Montigny R and Goffé B (2006) Pressure-temperature-time constraints on the Maghrebide mountain building: evidence from the Rif-Betic transect (Morocco, Spain), Algerian correlations, and geodynamic implications. Comptes Rendus Geoscience 338, 92-114.

Miyashiro A (1961) Evolution of metamorphic belts. Journal of Petrology 2, 277-311.

Montel JM, Kornprobst J and Vielzeuf D (2000) Preservation of old U-Th- $\mathrm{Pb}$ ages in shielded monazite: example from the Beni Bousera Hercynian kinzigites (Morocco). Journal of Metamorphic Geology 18, 335-42.
Negro F, Beyssac O, Goffe B, Saddiqi O and Bouybaouene ML (2006) Thermal structure of the Alboran Domain in the Rif (northern Morocco) and the Western Betics (southern Spain). Constraints from Raman spectroscopy of carbonaceous material. Journal of Metamorphic Geology 24, 309-27.

Oxburgh ER and Turcotte DL (1970) Thermal structure of island arcs. Geological Society of America Bulletin 81, 1665-88.

Pearce JA (1982) Trace element characteristics of lavas from destructive plate boundaries. In Andesites: Orogenic Andesites and Related Rocks (ed. RS Thorpe), pp. 525-48. Chichester; New York: Wiley.

Pearce JA (1983) Role of the sub-continental lithosphere in magma genesis at active continental margins. In Continental Basalts and Mantle Xenoliths (eds CJ Hawkesworth and MJ Norry), pp. 230-49. Nantwich, Cheshire: Shiva Publications.

Pearce JA (1996) A user's guide to basalt discrimination diagrams. In Trace Element Geochemistry of Volcanic Rocks: Applications for Massive Sulphide Exploration (ed. DA Wyman), pp. 79-113. Geological Association of Canada, Short Course Notes vol. 12.

Pearce JA and Cann JR (1973) Tectonic setting of basic volcanic rocks determined using trace element analyses. Earth and Planetary Science Letters 19, 290-300.

Pearce JA, Nigel B, Harris N and Tindle A (1984) Trace element discrimination diagrams for the tectonic interpretation of granitic rocks. Journal of Petrology 25, 956-83.

Peccerillo A and Taylor SR (1976) Geochemistry of Eocene calc-alkaline volcanic rocks from the Kastamonu area, Northern Turkey. Contributions to Mineralogy and Petrology 58, 63-81.

Platt JP, Argles TW, Carter A, Kelley SP, Whitehouse MJ and Lonergan L (2003) Exhumation of the Ronda peridotite and its crustal envelope: constraints from thermal modelling of a P-T-time array. Journal of the Geological Society, London 160, 655-76.

Poitrasson F, Chenery S and Shepherd TJ (2000) Electron microprobe and LA-ICP-MS study of monazite hydrothermal alteration: implications for $\mathrm{U}-\mathrm{Th}-\mathrm{Pb}$ geochronology and nuclear ceramics. Geochimica et Cosmochimica Acta 64, 3283-97.

Potdevin J-L, Cotonian C and Bertrand H (1989) Diffusion model for magmatic reaction. An example of amphibole breakdown in the trachytic dome of Monac (French Massif Central). Comptes Rendus de l'Academie des Sciences Paris 309, 63-8.

Rollinson H (1993) Using Geochemical Data: Evaluation, Presentation, Interpretation, pp. 150-54. Harlow, Essex: Longman Scientific \& Technical.

Roser BP and Nathan S (1997) An evaluation of elemental mobility during metamorphism of a turbidite sequence (Greenland Group, New Zealand). Geological Magazine 134, 219-34.

Rossetti F, Theye T, Lucci F, Bouybaouene ML, Dini A,Gerdes A, Phillips D and Cozzupoli D (2010) Timing and modes of granite magmatism in the core of the Alboran Domain (Rif chain, northern Morocco): implications for the Alpine evolution of the western Mediterranean. Tectonics 29, TC2017, doi: 10.1029/2009TC002487.

Royden LH (1993) Evolution of the retreating subduction boundaries formed during continental collision. Tectonics 12, 629-38.

Ruiz-Cruz MD and De Galdeano CS (2012) Diamond and coesite in ultrahighpressure-ultrahigh-temperature granulites from Ceuta, Northern Rif, northwest Africa. Mineralogical Magazine 76, 683-704.

Ruiz-Cruz MD and De Galdeano CS (2013) Petrology of microdiamond-bearing schists from the Torrox unit, Betic Cordillera, Spain. European Journal of Mineralogy 25, 919-33.

Schandl ES and Gorton MP (2002) Application of high field strength elements to discriminate tectonic settings in VMS environments. Economic Geology 97, 629-42.

Schiffman P, Elders WA, Williams AE, McDowell SD and Bird DK (1984) Active metasomatism in the Cerro Prieto geothermal system, Baja California, Mexico: a telescoped low-pressure, low-temperature metamorphic facies series. Geology 12, 12-15.

Seydoux-Guillaume A-M, Montel J-M, Bingen B, Bosse V, de Parseval P, Paquette J-L, Janots E and Wirth R (2012) Low-temperature alteration of monazite: fluid mediated coupled dissolution-precipitation, irradiation 
damage, and disturbance of the $\mathrm{U}-\mathrm{Pb}$ and $\mathrm{Th}-\mathrm{Pb}$ chronometers. Chemical Geology 330-331, 140-58.

Spakman W and Wortel R (2004) A tomographic view on western Mediterranean geodynamics. In The TRANSMED Atlas. The Mediterranean Region from Crust to Mantle (eds W Cavazza, FM Roure, W Spakman, GM Stampfli and PA Ziegler), pp. 31-52. Berlin: Springer.

Steiger RH and Jäger E (1977) Subcommission on geochronology: convention on the use of decay constants in geo- and cosmochronology. Earth and Planetary Science Letters 36, 359-62.

Timoulali Y, Djellit H, Hahou Y, Jabour N and Merrouch R (2014) New evidence of delamination in the Western Alboran Sea: geodynamic evolution of the Alboran domain and its margins. Journal of Geodynamics 77, 206-16.

Torres-Roldan RL, Poli G and Peccerillo A (1986) An early Miocene arctholeiitic magmatic dyke event from the Alboran sea: evidence for precollision subduction and back-arc crustal extension in the westernmost Mediterranean. Geologische Rundschau 75, 219-34.

Turner SP, Platt JP, George RMM, Kelley SP, Pearson DG and Nowell GM (1999) Magmatism associated with orogenic collapse of the Betic-Alboran Domain, SE Spain. Journal of Petrology 40, 1011-36.

Van Hinsbergen DJJ, Vissers RLM and Spakman W (2014) Origin and consequences of western Mediterranean subduction, rollback, and slab segmentation. Tectonics 33, 393-419.
Vergés J and Fernàndez $\mathbf{M}$ (2012) Tethys-Atlantic interaction along the IberiaAfrica plate boundary: the Betic-Rif orogenic system. Tectonophysics 579 $144-72$.

Villaseñor A, Chevrot S, Harnafi M, Gallart J, Pazos A, Serrano I, Córdoba D, Pulgar JA and Ibarra P (2015) Subduction and volcanism in the Iberia-North Africa collision zone from tomographic images of the upper mantle. Tectonophysics 663, 238-49.

Williams ML, Jercinovic MJ, Harlov DE, Budzyń B and Hetherington CJ (2011) Resetting monazite ages during fluid-related alteration. Chemical Geology 283, 218-25.

Willner AP (2005) Pressure-temperature evolution of a late Palaeozoic paired metamorphic belt in north-central Chile $\left(34^{\circ}-35^{\circ} 30^{\prime} \mathrm{S}\right)$. Journal of Petrology 46, 1805-33.

Willner AP, Glodny J, Gerya TV, Godoy E and Massonne H-J (2004) A counterclockwise PTt path of high-pressure/low-temperature rocks from the Coastal Cordillera accretionary complex of south-central Chile: constraints for the earliest stage of subduction mass flow. Lithos 75, 283-310.

Winchester JA and Floyd PA (1977) Geochemical discrimination of different magma series and their differentiation products using immobile elements. Chemical Geology 20, 325-43.

Zheng Y-F, Chen R-X and Zhao Z-F (2009) Chemical geodynamics of continental subduction-zone metamorphism: insights from studies of the Chinese Continental Scientific Drilling (CCSD) core samples. Tectonophysics $475,327-58$. 